\title{
AVALIAÇÃO DO RISCO DE OCORRÊNCIA DE GEADAS NO ESTADO DE SANTA CATARINA
}

\author{
JOSÉ GABRIEL DA SILVA
}

Engenheiro Agrônomo

Orientador: Prof ${ }^{\circ}$. Dr. PAULO CESAR SENTELHAS

\begin{abstract}
Dissertação apresentada à Escola Superior de Agricultura "Luiz de Queiroz", da Universidade de São Paulo, para obtenção do título de Mestre em Agronomia, Área de Concentração:

Agrometeorologia.
\end{abstract}

PIRACICABA

Estado de São Paulo - Brasil

Janeiro / 2000 


\section{ERRATA:}

As correções apresentadas a seguir estão fundamentadas nas sugestões fornecidas pela banca examinadora.

Evitando dupla interpretação no texto, na primeira linha da página 4: onde se lê "permanecem com temperatura constante", leia-se "voltam ao gradiente térmico real".

$\mathrm{Na}$ Página 11, terceiro parágrafo, segunda linha: onde se lê "são susceptíveis ao congelamento", leia-se "são mais vulneráveis ao congelamento".

A partir da página 17: onde se lê Ponte Cerrada, leia-se Ponte Serrada.

Página 17, na "Tabela 3": onde se lê altitude $(\mathrm{m})$ igual a "1800m" para São Joaquim, leia-se "1415m".

Página 25, segunda linha e Página 34, segundo parágrafo, segunda linha: onde se lê "1800m", leia-se "1415m".

Página 25: substituir "Figura 3" por:

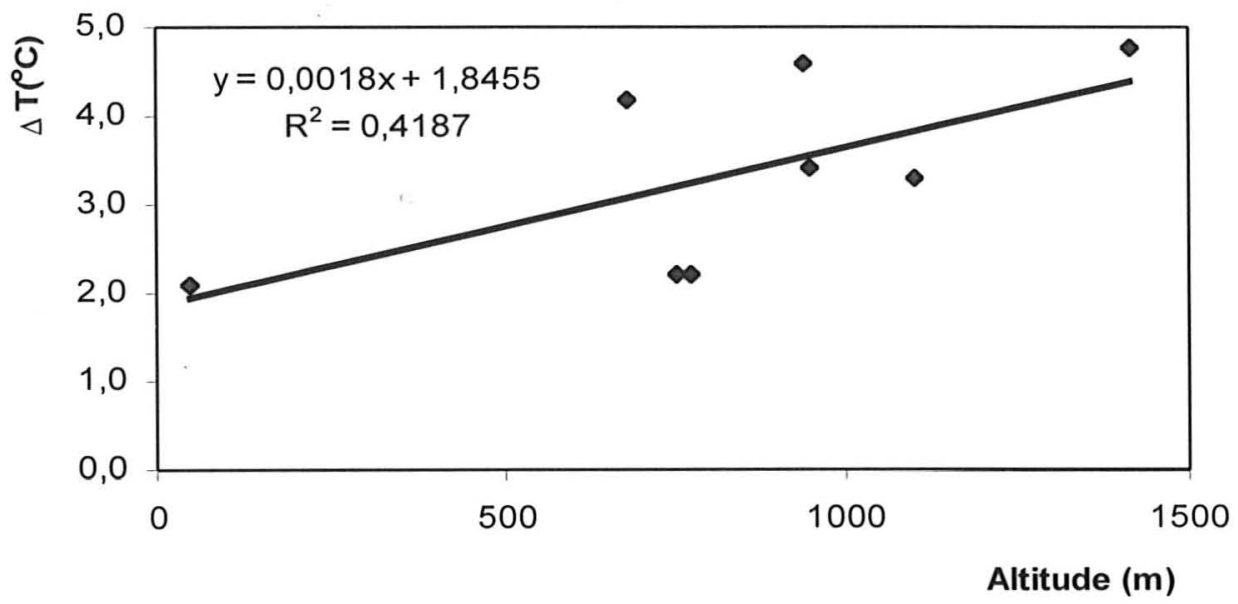

Página 25, segundo parágrafo, segunda linha: onde se lê " $44,64 \% "$, leia-se "41,87\%".

Página 36, terceira linha: onde se lê "Isso se deve a sua maior latitude...", leia-se "Isso se deve, em parte, à sua maior latitude..." 


\title{
Dados Internacionais de Catalogação na Publicação (CIP) DIVISÃO DE BIBLIOTECA E DOCUMENTAÇÃO - Campus "Luiz de Queiroz"/USP
}

\author{
Silva, José Gabriel da \\ Avaliação do risco de ocorrência de geadas no Estado de Santa Catarina / José
} Gabriel da Silva. - - Piracicaba, 2000.

67p. : il

Dissertação (mestrado) - - Escola Superior de Agricultura Luiz de Queiroz, 2000.

Bibliografia.

1. Agricultura 2. Climatologia 3. Comercialização agrícola 4. Geada 5. Manejo 6. Produto agrícola 7. Relaçăo solo-planta-atmosfera 8 . Relaçăo temperatura-meio ambiente I. Título

$$
C D D .630 \cdot 2515
$$


À minha filha Thuani Silva, razão maior de minha vida DEDICO

A meus pais, José da Silva e Alexandra da Silva e a Vilson Felinto Santos, Janete Teixeira Santos e Luanda Santos OFEREÇO 
“ AND EVERY HOUR OF EVERY DAY I'M LEARNING MORE THE MORE I LEARN, THE LESS I KNOW ABOUT BEFORE THE LESS I KNOW, THE MORE I WANT TO LOOK AROUND DIGGING DEEP FOR CLUES ON HIGHER GROUND “

"PROMISES AND LIES " "

\begin{abstract}
O HOMEM APRESSADO SEMEIA LEGUMES PARA A SUA MESA DE AMANHÃ. O HOMEM PRUDENTE CULTIVA TRIGO PARA O FUTURO PÃO. O HOMEM SÁBIO, PORÉM, ADICIONA A ESSAS SEMENTEIRAS, A VIDA, EM SI MESMA A FIM DE ESTAR SEMPRE EM PAZ.
\end{abstract}

JOANNA DE ÂNGELIS

"Responsabilidade "

\author{
SARÀ, SARÀ L'AURORA \\ PER ME SARÀ COSİ \\ SARÀ, SARÀ DI PIÙ ANCORA \\ TUTTO IL CHIARO CHE FARÀ..
}

EROS RAMAZZOTTI

"L'aurora " 


\section{AGRADECIMENTOS}

A Deus, pai todo poderoso, benevolente pela minha existência.

Aos meus pais que deram-me a vida e educaram-me magnificamente nos principios do bem.

À minha família que compartilhou os momentos acadêmicos com grande entusiasmo.

À Escola Superior de Agricultura Luiz de Queiroz da Universidade de São Paulo, que abriu-me as portas do conhecimento em Pesquisa Superior.

Ao Departamento de Física e Meteorologia da ESALQ, USP, que acreditou no meu trabalho e deu-me chances de concluí-lo.

À EPAGRI pela suporte computacional e fornecimento dos dados apresentados neste trabalho.

À Universidade Federal de Santa Catarina, pelo apoio e suporte nos trabalhos de análise.

Ao Dr. Valter Barbieri, amigo e orientador da primeira fase deste trabalho.

Ao Dr. Paulo Cesar Sentelhas, amigo e orientador na fase final dos trabalhos, que deu-me apoio, com espírito de liderança e dinamismo.

Aos Professores Nilson A. Villa Nova, Luiz Roberto Angelocci, Antonio Roberto Pereira, Sérgio Oliveira Moraes, Klaus Reichardt, Carlos Alberto Vettorazzi, pelos valiosos ensinamentos durante a realização do curso.

À Dra. Ana Rita Rodrigues Vieira pela postura amiga e confiança demostrada durante meu período acadêmico.

A Angelo Mendes Massignam - EPAGRI - Campos Novos, pelo apoio no início dos trabalhos com fornecimento de grande parte do material de pesquisa. 
Especialmente a Lucietta Martorano, Pesquisadora da EMBRAPAVSolos, pelo seu equilibrio, serenidade, deu-me o impulso definitivo para o final dos trabalhos.

À Luanda Santos, companheira e amiga, que valorizou-me e deu-me forças para a conclusão dessa dissertação.

Aos Srs. Vilson Felinto Santos, Janete Teixeira Santos e Tiago Santos, que acolheram-me e deram amparo material durante o andamento das pesquisas em Florianópolis.

Aos Srs. Arnoldo Gomes Filho, Eliana Maria Gomes, Charles Willians Gomes e Fellipe Willians Gomes pelo auxilio inicial na jornada em Piracicaba e o apoio nas horas mais importantes.

Ao Colega Francisco Adriano Pereira, pelo incentivo e colaboração durante o curso.

Aos meus amigos da Vila de Pós Graduação "Ratinho, Vandeco, Regis, Claudinha, Jonas, Lacerdinha, Valter e Nôr" pelo carinho e apoio na convivência diária durante o Curso.

A todos os amigos de curso: Rosa Maria N. dos Santos, Zilda de Fátima Mariano, Juan Rojas Delgado, Angelica Picini, Adriana Vieira de Camargo Moraes e Ricardo Pezzopane, que preocuparam-se com minhas dificuldades, tomando muitas vezes minhas dores para si próprios

Aos funcionários do Departamento de Ciências Exatas: Robson Luiz Tuon, Ana Maria Michelon, Fernando Novello, Francisco Bernardo Dias, Vanderlino Assunção e Edivaldo Modesto pela boa convivência durante o Curso.

Enfim, meus agradecimentos sinceros as todos os colegas que direta ou indiretamente contribuiram para a realização deste trabalho. 


\section{SUMARIO}

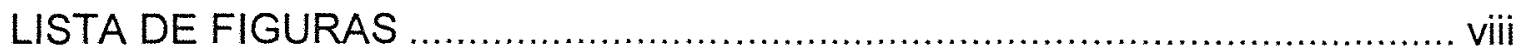

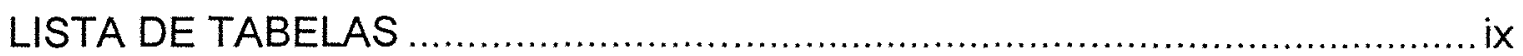

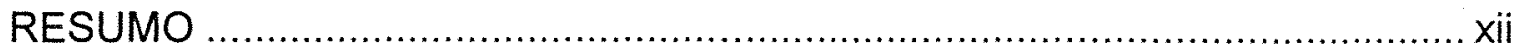

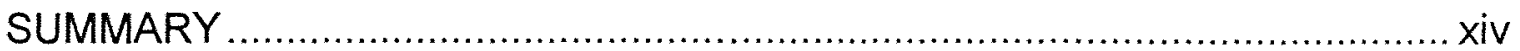

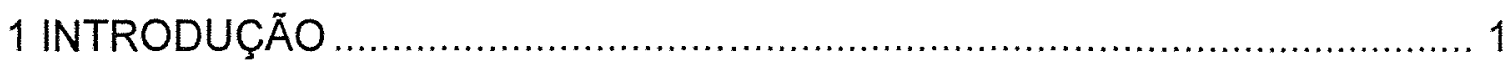

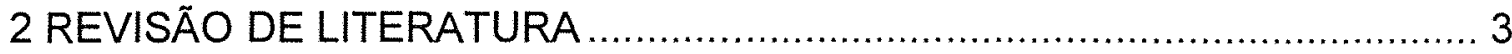

2.1 Princípios físicos da ocorrência de geadas ................................................................. 3

2.2 Condições atmosféricas favoráveis a ocorrência de geadas de radiação ......................... 4

2.3 Fatores que afetam a ocorrência de geadas ............................................................. 4

2.4 Relação temperatura mínima do ar e da relva .............................................................. 5

2.5 Frequência de ocorrência de geadas no Brasil.......................................................... 6

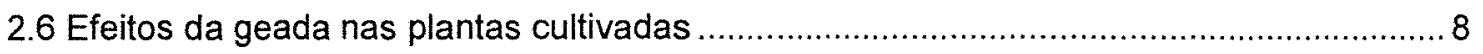

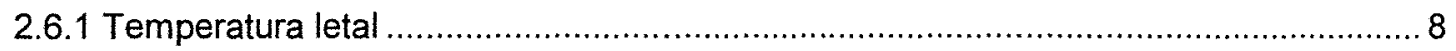

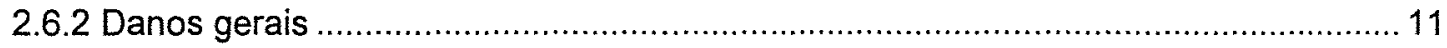

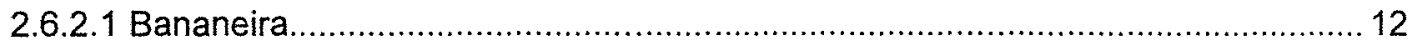

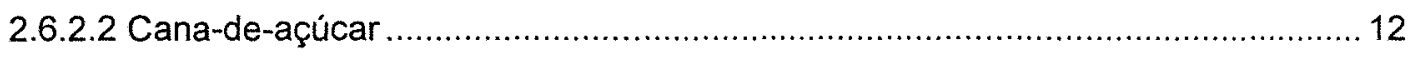

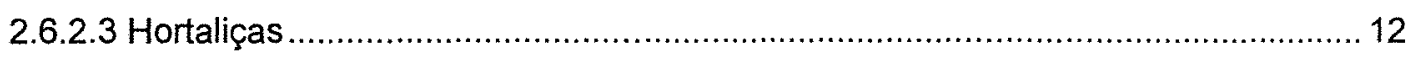

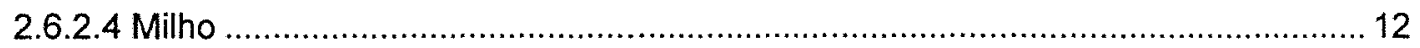

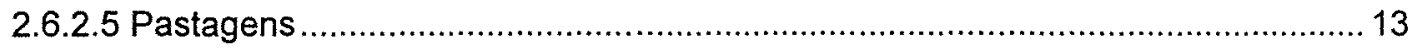

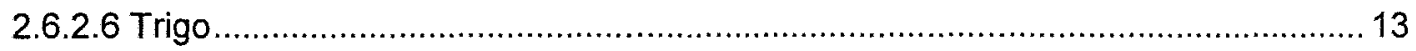

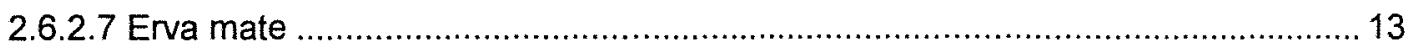

2.7 Medidas preventivas para minimização dos efeitos da geada ..................................... 13

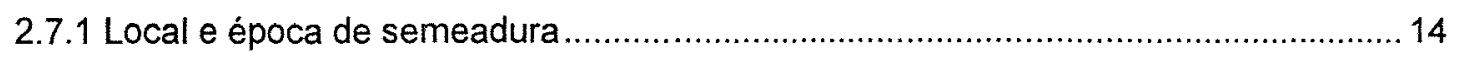

2.7.2 Utilização de variedades resistentes............................................................. 14

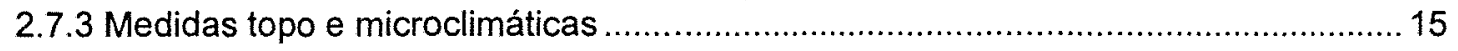

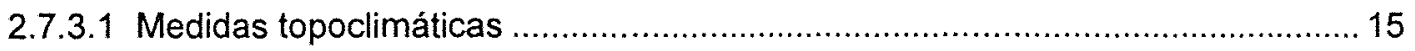

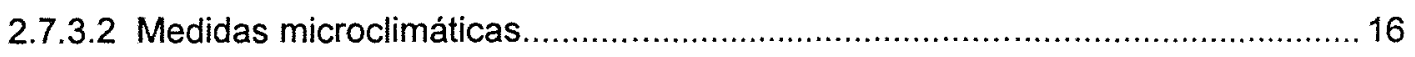

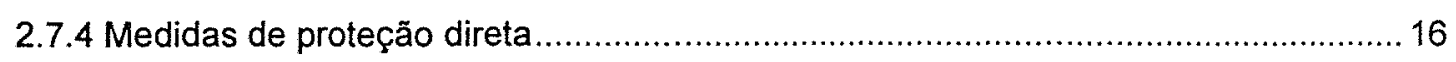

3 MATERIAL E MÉTODOS ......................................................... 17

3.1 Dados de temperatura mínima do ar no abrigo meteorológico e na relva ...................... 17

3.2 Determinação da diferença média e da correlação entre a temperatura mínima do ar no abrigo meteorológico e na relva 
3.3 Probabilidade de ocorrência de determinada diferença de temperatura mínima

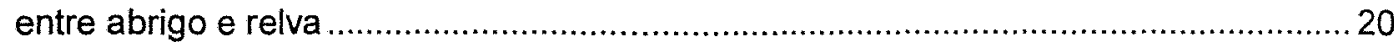

3.4 Probabilidade mensal de ocorrência de geadas de diferentes intensidades ................ 21

3.5 Probabilidade de ocorrência de geadas de diferentes intensidades em cada

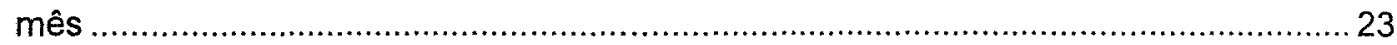

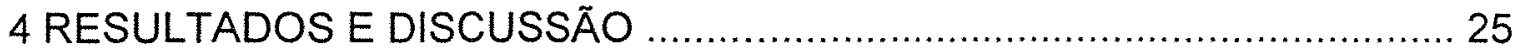

4.1 Determinação da diferença média e da correlação entre a temperatura mínima do ar no abrigo meteorológico e na relva

4.2 Probabilidade de ocorrência de determinada diferença de temperatura entre o

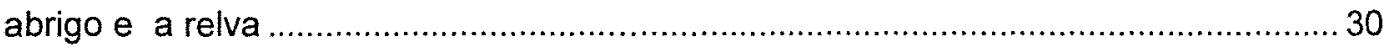

4.3 Probabilidade mensal de ocorrência de geadas de diferentes intensidades ................33

4.4 Probabilidade de ocorrência de geadas de diferentes intensidades em cada mês 38

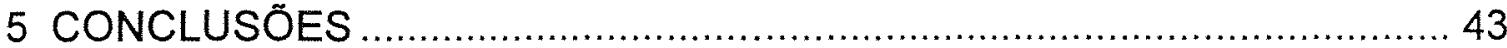

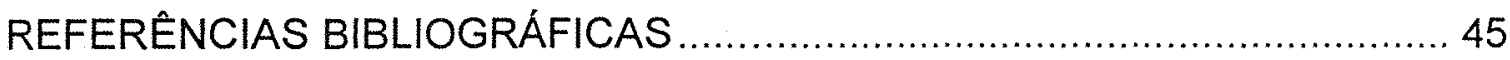




\section{LISTA DE FIGURAS}

Figura 1 - Localização geográfica dos postos meteorológicos do Estado de Santa Catarina, cujos dados foram utilizados no presente estudo

Figura 2 - Esquema indicando os gradientes térmicos diurno e noturno num dia de geada, onde observa-se a inversão térmica, a temperatura mínima do abrigo (Tma), na relva (Tmr) e a diferença entre elas $(\Delta T)$

Figura 3 - Relação entre a média da diferança de temperatura mínima do abrigo meteorológico e da relva $(\Delta T)$ com a altitude.

Figura 4 - Relação entre a temperatura mínima do ar obtida na relva e no abrigo para as localidades de Campos Novos, Chapecó, Lages e Ponte Cerrada, no Estado de Santa Catarina. 28

Figura 5 - Relação entre a temperatura mínima do ar obtida na relva e no abrigo para as localidades de São Joaquim, São Miguel D'Oeste, Urussanga e Videira, no Estado de Santa Catarina. 29

Figura 6 - Frequência observada e estimada pelos modelos probabilisticos: normal, gama e log normal, da diferença de temperatura minima abrigo-relva em noites de geada, em 8 localidades de Santa Catarina. 


\section{LISTA DE TABELAS}

Tabela 1. Temperatura letal $\left({ }^{\circ} \mathrm{C}\right)$ de culturas em diferentes estádios fenológicos, ao nivel de folha e no abrigo meteorológico.

Tabela 2. Temperatura letal $\left({ }^{\circ} \mathrm{C}\right)$ de diferentes culturas perenes, ao nivel da folha e no abrigo meteorológico. 10

Tabela 3. Relação das localidades utilizadas no presente estudo com as respectivas coordenadas geográficas.

Tabela 4. Relação das localidades e respectivos números de anos utilizados para a obtenção da diferença média e da correlação entre a temperatura mínima do ar no abrigo e na relva.

Tabela 5. Niveis de intensidade ou severidade de geadas com respectiva denominação e intervalo de temperatura na relva. Adaptado de Acosta et al.(1971).

Tabela 6. Relação das localidades e respectivos números de anos utilizados para a determinação da probabilidade de ocorrência de geadas.

Tabela 7. Medidas de tendência da diferença de temperatura mínima entre 0 abrigo e a relva para 8 localidades do Estado de Santa Catarina.

Tabela 8. Valores do teste do qui-quadrado $\left(\chi^{2}\right)$ para três modelos probabilisticos no ajuste da diferença de temperatura mínima do ar entre abrigo e relva, em noites de geada para 8 localidades de Santa Catarina $\left(\chi^{2} 0,05\right.$ Tabela $\left.=21,03\right)$.

Tabela 9. Probabilidade de ocorrência da diferença de temperatura mínima do ar entre 0 abrigo e a relva $(\Delta T)$ em noites de geada, de diversas localidades do Estado de Santa Catarina.

Tabela 10. Frequência relativa mensal de ocorrência de geadas de diferentes intensidades na localidade de Campos Novos (SC). 
Tabela 11. Frequência relativa mensal de ocorrência de geadas de diferentes intensidades na localidade de Chapecó (SC).

Tabela 12. Frequência relativa mensal de ocorrência de geadas de diferentes intensidades na localidade de Lages (SC).

Tabela 13. Frequência relativa mensal de ocorrência de geadas de diferentes intensidades na localidade de Ponte Cerrada (SC).

Tabela 14. Frequência relativa mensal de ocorrência de geadas de diferentes intensidades na localidade de São Joaquim (SC).

Tabela 15. Frequência relativa mensal de ocorrência de geadas de diferentes intensidades na localidade de São Miguel D'Oeste (SC).

Tabela 16. Frequência relativa mensal de ocorrência de geadas de diferentes intensidades na localidade de Urussanga (SC)

Tabela 17. Frequência relativa mensal de ocorrência de geadas de diferentes intensidades na localidade de Videira (SC).

Tabela 18. Frequência relativa da ocorrência de geadas em diferentes intensidades em cada mês para a localidade de Campos Novos (SC).

Tabela 19. Frequência relativa da ocorrência de geadas em diferentes intensidades em cada mês para a localidade de Chapecó (SC).

Tabela 20. Frequência relativa da ocorrência de geadas em diferentes intensidades em cada mês para a localidade de Lages (SC). 39

Tabela 21. Frequência relativa da ocorrência de geadas em diferentes intensidades em cada mês para a localidade de Ponte Cerrada (SC). 40

Tabela 22. Frequência relativa da ocorrência de geadas em diferentes intensidades em cada mês para a localidade de São Joaquim (SC). 
Tabela 23. Frequência relativa da ocorrência de geadas em diferentes intensidades em cada mês para a localidade de São Miguel D'Oeste (SC).

Tabela 24. Frequência relativa da ocorrência de geadas em diferentes intensidades em cada mês para a localidade de Urussanga (SC).

Tabela 25. Frequência relativa da ocorrência de geadas em diferentes intensidades em cada mês para a localidade Videira (SC) 


\title{
AVALIAÇÃO DO RISCO DE OCORRÊNCIA DE GEADAS NO ESTADO DE SANTA CATARINA
}

\author{
Autor: JOSÉ GABRIEL DA SILVA \\ Orientador: Prof Dr. PAULO CESAR SENTELHAS
}

\section{RESUMO}

A geada é um dos muitos problemas que os agricultores catarinenses enfrentam durante o período de produção e de comercialização de seus produtos, especialmente, quando elas ocorrem precoce ou tardiamente. Como a utilização de medidas mais eficientes de combate às geadas são onerosas, a alternativa passa a ser o planejamento das atividades agrícolas de acordo com as condições climáticas. Para tanto, informações relativas à frequência de ocorrência e às intensidades das geadas são fundamentais. Com o objetivo de determinar a relação entre a temperatura mínima da relva (Tmr) e do abrigo meteorológico (Tma) e a probabilidade mensal de geadas de diferentes intensidades efetuou-se o presente trabalho. Foram utilizados dados de temperatura mínima do ar obtidos na relva e no abrigo meteorológico de oito localidades catarinenses: Campos Novos, Chapecó, Lages, Ponte Cerrada, São Joaquim, São Miguel D'Oeste, Urussanga e Videira, pertencentes à Empresa de Pesquisa Agropecuária e Extensão Rural de Santa Catarina (EPAGRI). Primeiramente, foram processados os dados de Tmr e Tma, estabelecendo-se a diferença média entre ambas $(\Delta T)$ em noites de geada. Posteriormente, os dados da $\Delta \mathrm{T}$ foram divididos em intervalos de classe de modo a se obter sua distribuição, a qual foi aplicada três funções probabilisticas: normal, log-normal e gama, para a determinação de sua probabilidade de ocorrência. Em seguida, determinou-se por meio de frequência relativa a probabilidade mensal de ocorrência de geadas de diferentes intensidades e também a probabilidade de geadas de diferentes intensidades em cada mês. Os resultados mostraram que o $\Delta \mathrm{T}$ variou de 2,1 a $4,8^{\circ} \mathrm{C}$ entre as localidades analisadas, indicando haver efeito da 
altitude nessa diferença. Foram geradas equações de estimativa da Tmr em função de Tma, sendo essas polinomiais. Essas equações foram utilizadas, posteriormente, para a recuperação de parte dos dados de Tmr. Com relação à probabilidade de ocorrência de dada $\Delta T$, utilizou-se a função normal para as localidades de Chapecó, Lages, Ponte Cerrada, São Miguel D'Oeste e Videira, a função log-normal para Campos Novos e Urussanga e a função gama para São Joaquim. As maiores probabilidades de $\Delta T$ encontram-se na faixa de 0,1 a $3,0^{\circ} \mathrm{C}$ para Campos Novos, São Miguel D'Oeste, Urussanga e Videira. Em Ponte Cerrada a maior probabilidade é de $\Delta \mathrm{T}$ entre 2,1 e $4,0^{\circ} \mathrm{C}$, em Chapecó e São Joaquim entre 3,1 e $5,0^{\circ} \mathrm{C}$ e em Lages entre 4,1 e $6,0^{\circ} \mathrm{C}$. Com os dados de $\mathrm{Tmr}$ e os respectivos valores de Tma obteve-se para cada localidade a probabilidade mensal de ocorrência de geadas de diferentes intensidades, verificando-se que a maior probabilidade de ocorrência de geadas de qualquer intensidade distribuem-se de maio a setembro em São Miguel D'Oeste, de maio a novembro em Urussanga, de abril a outubro em Campos Novos, Chapecó e Ponte Cerrada, de março a novembro em Videira, de fevereiro a dezembro em Lages e de janeiro a dezembro em São Joaquim. As maiores probabilidades de ocorrência de geadas precoces ou tardias ocorrem em Lages e São Joaquim. A probabilidade de ocorrência de geadas de diferentes intensidades em cada mês também foi determinada. Em todas as localidades analisadas, a geada mais frequente é a fraca ( $T \mathrm{mr}=0,0 \mathrm{a}$ $-1,9^{\circ} \mathrm{C}$ ), com probabilidade de ocorrência variando de 36 a $92 \%$. Somente nas localidades de Lages, Videira e São Joaquim há a possibilidade de ocorrência de geadas extremamente fortes $\left(\mathrm{Tmr}<-9,9^{\circ} \mathrm{C}\right.$ ), apesar das baixas probabilidades. Espera-se com esse trabalho oferecer ao setor produtivo, aos órgão de previsão e monitoramento climático, aos agricultores catarinenses e à sociedade, em geral, dados e informações inéditas que auxiliem o planejamento agrícola da região. 


\title{
EVALUATION OF FROST RISK OCCURRENCE IN SANTA CATARINA STATE - BRAZIL
}

\author{
Author: JOSÉ GABRIEL DA SILVA \\ Advisor: Prof ${ }^{\circ}$. Dr. PAULO CESAR SENTELHAS
}

\section{SUMMARY}

The frost is one of the many problems that the catarinenses farmers faces during the production period, especially, when it happen earlier or later. As the use of the most efficient practices to combat frosts is onerous, the alternative becomes to plan the agricultural activities in agreement with the climatic conditions. For so much, information about the occurrence frequency and the intensities of the frosts are fundamental. With the objective of determining the relationship between the grass (Tmr) and screen (Tma) minimum temperature and the monthly probability of frosts at different intensities was made the present work. Data of air minimum temperature obtained on the grass and in the meteorological screen of eight places in the state of Santa Catarina: Campos Novos, Chapecó, Lages, Ponte Cerrada, São Joaquim, São Miguel D'oeste, Urussanga and Videira, belonging to the Company of Agricultural Research and Rural Extension of Santa Catarina (EPAGRI), were used to study this subjects. Firstly, the data of Tmr and Tma were processed, settling down the average difference between them $(\Delta T)$ in frost nights. Later on, the data of $\Delta T$ were divided in intervals of classes to obtain its distribution, which three functions probabilistics were applied: normal, log-normal and gama, for the determination of its occurrence probability. Soon after, it was determined, by relative frequency, the monthly probability of occurrence of frosts at different intensities and also the probability of frosts at different intensities in each month. The results showed that $\Delta T$ varied from 2,1 to $4,8^{\circ} \mathrm{C}$ among the analyzed places, 
indicating there is effect of the altitude in this difference. Equations of estimate of Tmr were generated in function of Tma, being those polinomials. Those equations were used, later on, to recovery part of the Tmr data. With relation the occurrence probability of given $\Delta T$, the normal function was used to the places of Chapecó, Lages, Ponte Cerrada, São Miguel D'Oeste, and Videira, the log-normal function for Campos Novos and Urussanga and the gama function to São Joaquim. The largest probabilities of $\Delta T$ is from 0,1 to $3,0^{\circ} \mathrm{C}$ for Campos Novos, São Miguel D'Oeste, Urussanga, and Videira. In Ponte Cerrada the largest probability of $\Delta T$ is between 2,1 and $4,0^{\circ} \mathrm{C}$, in Chapecó and São Joaquim between 3,1 and $5,0^{\circ} \mathrm{C}$ and in Lages between 4,1 and $6,0^{\circ} \mathrm{C}$. With the data of $\mathrm{Tmr}$ and the respective values of Tma it was obtained to each place the monthly probability of frosts occurrence at different intensities, being verified that the largest probability of frosts occurrence of any intensity is distributed from May to September in São Miguel D'Oeste, from May to November in Urussanga, from April to October in Campos Novos, Chapecó, and Ponte Cerrada, from March to November in Videira, from February to December in Lages and from January to December in São Joaquim. The largest probabilities of occurrence of earlier or later frosts happen in Lages and São Joaquim. The probability of frosts occurrence at different intensities in every month it was also determined. In every analyzed places, the most frequent frost is weak ( $\mathrm{Tmr}=0,0$ to $-1,9^{\circ} \mathrm{C}$ ), with occurrence probability varying from 36 to $92 \%$. Only in Lages, Videira and São Joaquim there is the possibility of occurrence of extremely strong frosts ( $T \mathrm{mr}<-9,9^{\circ} \mathrm{C}$ ), in spite of the low probabilities. It is waited with this work to offer to the productive section, to the forecast and climatic monitoring systems, to the catarinenses farmaers and to the society, in general, data and unpublished information that aid the agricultural planning of the state of Santa Catarina, Brazil. 


\section{INTRODUÇÃO}

A geada é um dos muitos problemas que os agricultores catarinenses enfrentam durante o período de produção e de comercialização de seus produtos, especialmente no que se refere às geadas precoces ou tardias, que na maioria das vezes, acontecem em momentos inesperados.

Como o aconselhamento sobre a conveniência ou a praticidade da adoção de métodos de prevenção ou defesa contra as geadas não é tarefa fácil, o mais eficiente passa a ser o planejamento das atividades de acordo com as condições climáticas e as exigências dos vegetais ou animais manejados.

Os danos causados por geadas vêm sendo pesquisados por muitos autores, sendo que uma das formas de se evitar tal problema é através da prevenção, que só é possível quando os agricultores têm acesso a informações sobre o período de ocorrência de geadas, frequência com que elas ocorrem e probabilidade para um dado evento.

A temperatura mínima do ar observada no abrigo meteorológico é importante informação no levantamento de geadas, sendo consideradas as temperaturas de $2^{\circ} \mathrm{C}$ a $3^{\circ} \mathrm{C}$ como limite abaixo dos quais se iniciam os danos (Camargo et al., 1993). No entanto, segundo Bootsma (1976a), um termômetro exposto na relva indica com melhor precisão as condiçōes de geada, pois reflete a atuação das condições meteorológicas que ocorrem durante o período noturno, como a velocidade do vento, a nebulosidade e a pressão parcial do vapor d'água, as quais influenciam o balanço de radiação.

Em face disso, torna-se de grande importância o conhecimento da diferença existente entre temperatura mínima do ar no abrigo meteorológico e na relva, para que a partir da primeira seja possivel se fazer inferências a respeito dos danos decorrentes das geadas. 
A diferença entre a temperatura mínima no abrigo e na relva depende de fatores atmosféricos associados aos topográficos e às características da superfície. Para as condições padrões de um posto meteorológico, as maiores diferenças irão ocorrer em noites de céu limpo, sem vento e com baixa umidade do ar, o que proporciona intensa emissão de energia (onda longa) pela superfície, intensificando também a inversão térmica.

Diante do exposto, o objetivo do presente trabalho é determinar, para 8 localidades do Estado de Santa Catarina, a diferença média entre a temperatura mínima do ar obtida em abrigo meteorológico e junto à relva, a probabilidade de ocorrência de determinada diferença entre o abrigo e a relva para cada localidade, a probabilidade mensal de ocorrência de geadas para diversos níveis de intensidade e a probabilidade de ocorrência de diferentes níveis de geada em cada mês. 


\section{REVISÃO DE LITERATURA}

Geada, sob o ponto de vista agronômico, é um fenômeno atmosférico que provoca a morte das plantas ou de suas partes (folhas, caule, frutos, ramos), em função da baixa temperatura do ar, que acarreta congelamento dos tecidos vegetais (Sentelhas et al., 1999). Sua ocorrência depende de uma série de fatores e resulta em graves prejuizos econômicos nos vários ramos da agricultura nos estados do Centro-Sul do Brasil, especialmente quando ocorrem precoce ou tardiamente.

\subsection{Princípios físicos da ocorrência de geadas}

Existem, basicamente, duas condições para a ocorrência de geadas: advecção de ar frio e emissão de radiação pela superficie (Valli, 1972). No entanto para Bootsma (1980), pode ainda existir uma terceira condição, que seria a ocorrência das duas condições acima, sucessivamente.

A geada advectiva ou de vento, é caracterizada pelo transporte de uma massa de ar fria, proveniente da região Polar, em direção ao Equador. No seu deslocamento, essa massa ocasiona ventos que ocorrem durante o dia e à noite, causando danos aos vegetais pelo abaixamento da temperatura e pela agitação das folhas (Camargo, 1997; Sentelhas et al.,1999).

As geadas de radiação, as mais comuns no Brasil, ocorrem após a entrada de uma massa de ar polar, fria e muito seca. Durante a atuação dessa massa de ar, as temperaturas da superfície se mantém acima do ponto de congelamento durante o dia, porém, após o pôr do sol, inicia-se o resfriamento da superfície devido a emissão de radiação na forma de ondas longas, enquanto camadas 
superiores permanecem com temperatura constante, o que caracteriza a "inversão térmica" (Valli, 1972).

Quando a concentração de vapor d'água na atmosfera é extremamente baixa, em condições de resfriamento, não ocorre a liberação do calor latente de condensação nem formação de camada diatérmica, o que caracteriza visualmente uma geada negra. Porém, quando a atmosfera apresenta vapor d'água, o resfriamento produz condensação desse vapor, com solidificação do orvalho sobre as plantas e coloração que carateriza a geada branca (Ometto, 1981).

\subsection{Condições atmosféricas favoráveis a ocorrência de geadas de radiação}

A geada de radiação acontece quando a atmosfera está absolutamente calma e o céu mantêm-se estrelado (Camargo, 1997). Além disso, condições de baixa umidade do ar favorecem a sua ocorrência. De acordo com Bootsma (1980), sob condições de nebulosidade, as nuvens absorvem e reemitem parte da radiação infravermelha proveniente da superficie, reduzindo o seu resfriamento, mesmo papel exercido pelo vapor d'água presente no ar. Já a ocorrência de ventos inibe a formação da inversão térmica devido a mistura das diferentes camadas de ar.

Bootsma (1976a) cita que ventos sinópticos bem como fluxos de ar induzidos pela topografia podem influenciar na estratificação do ar, afetando na ocorrência de geadas.

\subsection{Fatores que afetam a ocorrência de geadas}

Vários são os fatores que afetam a ocorrência de geadas (Camargo, 1972; Sentelhas et al.,1999). Na escala macroclimática, destacam-se a latitude, a altitude, proximidade ou não de massas de água (oceanalidade/continentalidade) e movimentos de massas de ar, especialmente as provenientes da região Polar. $\mathrm{Na}$ escala topoclimática, relacionada ao relevo, a configuração e exposição do terreno são de fundamental importância na manifestação do fenômeno, sendo que as 
áreas situadas em baixadas e na face de exposição sul, para o hemisfério Sul, são as mais sujeitas à ocorrência do fenômeno, respectivamente, pelo acúmulo intenso de ar frio e pela menor exposição ao sol no periodo de inverno. Já na escala microclimática, relacionada à cobertura do terreno, as geadas são mais severas nas áreas onde o solo estiver coberto por mato ou mulch, os quais funcionam como isolante térmico, impedindo a entrada de calor no solo durante o dia e consequentemente, sua liberação no período noturno.

\subsection{Relação temperatura mínima do ar e da relva}

Existe diferença entre a temperatura mínima obtida no abrigo meteorológico e na relva, e esta diferença é tão maior, quanto maior for a inversão térmica (Bootsma, 1976b).

Heldwein et al. (1988) observaram que a temperatura mínima do ar média mensal medida a $5 \mathrm{~cm}$ tanto sobre a relva como sobre o solo desnudo é sempre inferior àquela no abrigo meteorológico. De acordo com Boostma (1980), durante geadas de radiação, a diferença entre a temperatura mínima no abrigo meteorológico e na relva pode ser de $5^{\circ} \mathrm{C}$ ou mais.

Utilizando uma série de 10 anos, Pola (1993) calculou a diferença média relva-abrigo em noites de geada em Caçador (SC), verificando uma diferença de $2^{\circ} \mathrm{C}$ entre elas. Sentelhas et al. (1995), verificaram que as diferenças de temperaturas mínimas entre abrigo e relva apresentam uma variação acentuada entre os diversos locais do Estado de São Paulo, em média, de 3,3 a $5,7^{\circ} \mathrm{C}$, sendo essas variações explicadas pelas diferentes condições topográficas em que as estações meteorológicas estavam instaladas. Grodzki et al. (1996) encontraram diferenças entre $\mathrm{O}$ abrigo e a relva de $2,8^{\circ} \mathrm{C}$ a $3,8^{\circ} \mathrm{C}$, que de acordo com os autores, situam-se dentro da faixa encontrada na literatura.

Bootsma (1976b), utilizando regressão linear múltipla passo a passo, correlacionou vários elementos atmosféricos com a diferença de temperatura mínima entre o abrigo meteorológico e a relva, e verificou que a nebulosidade e a velocidade do vento foram as variáveis de maior significância na regressão, 
explicando cerca de $74 \%$ das variações da diferença de temperatura abrigo-relva. Sentelhas et al. (1995) obtiveram resultados semelhantes ao de Bootsma (1976b), para as condições do estado de São Paulo, onde $78 \%$ da variação da diferença de temperatura mínima entre o abrigo e a relva foi devida à velocidade do vento.

\subsection{Frequência de ocorrência de geadas no Brasil}

As geadas no Brasil tem causas e periodos de ocorrência diferenciados. Marengo et al. (1997), por exemplo, sem especificar os valores, descreveu que as temperaturas baixas no sudoeste do Brasil ocorrem nos meses de inverno e podem algumas vezes chegar a niveis de congelamento.

Camargo et al. (1993) e Camargo \& Alfonsi (1995) verificaram que os períodos de maior ocorrência de geadas para o Estado de São Paulo estão entre os meses de junho e agosto com valores entre $30 \%$ e $60 \%$ de probabilidade. Os autores ainda verificaram que as localidades situadas ao norte apresentam probabilidades inferiores a $30 \%$ de terem temperaturas menores do que $2^{\circ} \mathrm{C}$ medidas no abrigo meteorológico, ao passo na região Centro-Leste essa probabilidade varia entre $30 \%$ e $60 \%$ e na região Sul acima de $60 \%$.

Arruda et al. (1981), definiram modelos probabilisticos para estimativa de temperaturas inferiores a $2,0^{\circ} \mathrm{C}$, utilizando séries de temperaturas mínimas nos meses de junho e julho para a cidade de Campinas (SP). Os autores verificaram que a probabilidade de temperaturas menores que $2,0^{\circ} \mathrm{C}$ no mês de junho, é de $2,0 \%$ pela distribuição normal e de $1,0 \%$ pela distribuição de extremos. Já para o mês de julho os valores obtidos foram $0,05 \%$ para a distribuição de extremos e $0,07 \%$ para a distribuição normal.

No Estado do Paraná, a maior incidência de temperaturas abaixo de $0,0^{\circ} \mathrm{C}$ é na região Sul e Centro-Sul do Estado (Nery, 1998). Grodski et al. (1996) também observaram que, para o Estado do Paraná, as regiões Norte e Oeste apresentam os menores riscos de geadas, sendo sua ocorrência mais provável de maio a agosto ou maio a setembro, seguidas das regiões Centro-Sul e Sul, cujas prováveis ocorrências são entre abril e outubro ou abril e novembro. 
Para 16 localidades todo o Estado de Santa Catarina, Acosta et al. (1971), estimaram a probabilidade de ocorrência de geadas de primavera utilizando para esses cálculos 15 anos de observações de temperaturas do abrigo meteorológico. A partir desses dados os autores traçaram isolinhas de datas de ocorrência de geadas com 10,20 e $50 \%$ de probabilidade para diferentes intensidades e verificaram que quanto menor a probabilidade de ocorrência de geada, menor o risco de ocorrência de geada precoce. A mesma observação de probabilidade foi, posteriormente, observada por Acosta et al. (1972), que com 14 anos de dados de temperatura mínima do abrigo calcularam a probabilidade de ocorrência de geadas de outono para 15 localidades do Estado.

Steckert \& Althoff (1983), calcularam as probabilidades de ocorrência de geada por decêndio, considerando temperaturas menores que $3^{\circ} \mathrm{C}$, para as localidades de Chapecó e Campos Novos (SC). Os autores observaram que para a localidade de Chapecó, com 10 anos de dados, existe $9 \%$ de probabilidade de ocorrência de geada depois de 15 de setembro e também $9 \%$ de probabilidade de ocorrência antes de 25 de abril. Para a localidade de Campos Novos, com base em 8 anos de observações, existe $10 \%$ de probabilidade de ocorrência de geadas a partir de 15 de setembro e $10,9 \%$ de probabilidade das geadas ocorrerem antes do dia 15 de maio.

Ainda em Santa Catarina, Massignam \& Ditrich (1998) determinaram para diversas localidades o número médio de geadas e a probabilidade mensal de sua ocorrência, verificando que ambas podem ser estimadas em função da altitude, principal fator determinante das geadas neste Estado.

Muitos autores têm se preocupado com o estudo das frequências de ocorrência de geada no Estado do Rio Grande do Sul. Buriol (1976) verificou, para a localidade de Santa Maria, que a maior ocorrência de geadas se dá nos meses invernais podendo ocorrer também desde o mês de abril até setembro e outubro. Com vários níveis de probabilidade, Estefanel et al. (1988) calcularam, para um intervalo de dados de $-1,0^{\circ} \mathrm{C}$ a $+9,0^{\circ} \mathrm{C}$, a primeira data de ocorrência de geada para a localidade Santa Maria (RS): dia 5 de junho a $5 \%$ e 31 de julho com $55 \%$ de probabilidade, e para a última data de ocorrência de geada: dia 14 de agosto a $5 \%$ 
e 18 de junho com 55\% de probabilidade. Ainda para Santa Maria, Estefanel et al. (1991) verificaram para um intervalo de dados que foi de $-7,0^{\circ} \mathrm{C}$ até $+4,0^{\circ} \mathrm{C}$, datas diferentes de primeira e última geada, sendo estas: como primeiras datas 14 de abril a $5 \%$ e 24 de abril a $55 \%$ de probabilidade e como últimas datas 26 de outubro a $5 \%$ e 11 de setembro a $55 \%$ de probabilidade.

Hoffmann et al. (1994) para a localidade de Pelotas (RS) observaram que as temperaturas do ar inferiores a $0,0^{\circ} \mathrm{C}$ ocorrem entre 15 de maio e 3 de setembro.

Com dados de 15 anos de 50 localidades do Rio Grande do Sul, Acosta et al. (1973) verificaram em vários niveis de probabilidade, que as geadas de outono ocorreram em 49 das 50 localidades estudadas e somente em Torres, não houve registro de temperaturas minimas abaixo de $0,0^{\circ} \mathrm{C}$. Os autores ainda verificaram que a primeira geada se dá no dia 24 de junho na localidade de Lagoa Vermelha e a última geada ocorre no dia 30 de agosto na localidade de São Gabriel.

Estefanel et al. (1978) verificaram para 42 localidades, também do Rio Grande do Sul, que fatores geográficos como continentalidade, latitude, longitude e altitude tiveram pouca influência no desvio-padrão das temperaturas mínimas absolutas mensais e anuais, não sendo indicado, portanto, o uso de equações de regressão para estimativa das temperaturas mínimas absolutas

\subsection{Efeitos da geada nas plantas cultivadas}

\subsubsection{Temperatura letal}

Segundo Camargo et al. (1993), a suscetibilidade das culturas agrícolas às baixas temperaturas varia de acordo com a espécie e com seu estádio de desenvolvimento. Além disso, os danos causados às plantas também dependem do tempo em que permanecem sob condições propicias ao congelamento (Pola, 1993). Se, por exemplo, a temperatura permanece abaixo do ponto em que causa o congelamento, por um curto periodo, os danos podem ser pequenos; se, porém, permanecem abaixo do referido ponto por um período de várias horas, pode causar grandes prejuizos. 
Segundo Acosta et al. (1971), é muito dificil determinar as temperaturas criticas para as diversas culturas. Entretanto, em caráter mais geral, é possivel classificar as plantas de acordo com sua resistências às baixas temperaturas em: tenras, as quais são danificadas e mortas por quaisquer temperaturas iguais ou menores que zero; semi-resistentes, aquelas que sofrem com temperaturas abaixo de zero; e resistentes, as quais podem suportar geadas relativamente fortes sem serem mortas.

O processo de morte do tecido vegetal por baixas temperaturas é de natureza físico-química. Heber \& Santariurs (1973) descreveram o processo, o qual se inicia quando a temperatura letal da planta é atingida, havendo o congelamento da solução extracelular, que resulta em um desequilíbrio do potencial químico da água da solução intracelular em relação ao potencial químico da água da solução extraceluar, parcialmente congelada. Isso gera um processo contínuo de perda de água no sentido de dentro para fora da célula, o que acaba provocando sua desidratação ou o congelamento da solução intracelular.

Como, normalmente, as soluções tanto extra como intracelular tem uma maior concentração de solutos que a água pura, a temperatura do ponto de congelamento é menor do que zero, o que explica o fato da grande maioria das culturas somente sofrerem danos a partir de temperaturas foliares negativas.

Nas Tabelas 1 e 2 são apresentados exemplos de temperaturas letais ao nível da folha, ou seja, condição de exposição direta aos efeitos da geada e a correspondente temperatura letal no abrigo meteorológico.

Observa-se que a resistência ao dano provocado por baixas temperaturas varia com a espécie e também com a fase fenológica, como descrito por Camargo et al. (1993). 
Tabela 1. Temperatura letal $\left({ }^{\circ} \mathrm{C}\right)$ de culturas em diferentes estádios fenológicos, ao nivel de folha e no abrigo meteorológico.

\begin{tabular}{llcccccc}
\hline Resistência & Cultura & \multicolumn{2}{c}{ Germinação } & \multicolumn{2}{c}{ Florescimento } & \multicolumn{2}{c}{ Frutificação } \\
& & Folha & Abrigo & Folha & Abrigo & Folha & Abrigo \\
\hline Muito alta & Trigo & $-9,0$ & $-5,0$ & $-2,0$ & 2,0 & $-4,0$ & 0,0 \\
& Aveia & $-8,0$ & $-4,0$ & $-2,0$ & 2,0 & $-4,0$ & 0,0 \\
\multirow{2}{*}{ Alta } & Feijão & $-5,0$ & $-1,0$ & $-3,0$ & 1,0 & $-4,0$ & 0,0 \\
& Girassol & $-5,0$ & $-1,0$ & $-3,0$ & 1,0 & $-3,0$ & 1,0 \\
\multirow{2}{*}{ Média } & Soja & $-3,0$ & 1,0 & $-3,0$ & 1,0 & $-3,0$ & 1,0 \\
Baixa & Milho & $-2,0$ & 2,0 & $-2,0$ & 2,0 & $-3,0$ & 1,0 \\
& Sorgo & $-2,0$ & 2,0 & $-2,0$ & 2,0 & $-3,0$ & 1,0 \\
\multirow{2}{*}{ Muito baixa } & Algodão & $-1,0$ & 3,0 & $-2,0$ & 2,0 & $-3,0$ & 1,0 \\
& Arroz & $-0,5$ & 3,5 & $-1,0$ & 3,0 & $-1,0$ & 3,0 \\
\hline
\end{tabular}

Fonte: Ventskevich (1958) citado por Rosenberg et al. (1983) e por Sentelhas et al. (1999).

Tabela 2. Temperatura letal $\left({ }^{\circ} \mathrm{C}\right)$ de diferentes culturas perenes, ao nivel da folha e no abrigo meteorológico.

\begin{tabular}{lcc}
\hline Cultura - Variedade & Folha & Temperatura letal $\left({ }^{\circ} \mathrm{C}\right)$ \\
& Abrigo \\
\hline Abacate - Geada & $-4,0$ & 0,0 \\
Abacate - Pollock & $-1,0$ & 3,0 \\
Acerola & $-4,0$ & 0,0 \\
Anona - Cherimóia & $-6,0$ & $-2,0$ \\
Anona - Condessa & $-4,0$ & 0,0 \\
Banana - Guatemala & $-1,1$ & 2,9 \\
Café - Catuaí & $-4,0$ & 0,0 \\
Café - Coffea brevipes & $-2,0$ & 2,0 \\
Café - Coffea racemosa & $-5,0$ & $-1,0$ \\
Café - Icatú Vermelho & $-4,0$ & 0,0 \\
Café - Mundo Novo & $-4,0$ & 0,0 \\
Goiaba & $-4,0$ & 0,0 \\
Laranja - Jaffa & $-3,2$ & 0,8 \\
Maçã - Jonathan & $-2,5$ & 1,5 \\
Manga - Keitt & $-2,0$ & 2,0 \\
Maracujá & $-5,0$ & $-1,0$ \\
\hline
\end{tabular}

Fonte: Sentelhas et al. (1996); Sentelhas et al. (1999), Whiteman (1957) ${ }^{2}$ citado por Rosenberg et al. (1983).

'VENTSKEVICH, G.Z. Agrometeorology. OTS 60-5104, 1961.

${ }^{2}$ WHITEMAN, T.M. Freezing points of fruits, vegetables and florist stocks. U.S. Dept. of Agric. Marketing Res. Report n. 196, 32 p. 1957. 


\subsubsection{Danos gerais}

As baixas temperaturas nem sempre são sinônimo de prejuizos. Alguns patógenos e pragas não conseguem seu franco desenvolvimento quando as temperaturas permanecem baixas agindo como controle natural. A principal cultura do Estado, a maçã, é de clima temperado e as principais variedades como Golden, Gala e Fuji necessitam em média de 600 horas de frio para que ocorra a quebra natural da dormência (Petri, 1986).

Sentelhas et al. (1996) verificaram que existe tolerância também de frutiferas tropicais como goiaba, acerola, abacate, maracujá amarelo, dentre outras, a um nivel de acentuada tolerância entre temperaturas de $-4,0^{\circ} \mathrm{C}$ e $-6,0^{\circ} \mathrm{C}$. No entanto, outras culturas de outono como: cebola, tomate, feijão-de-vagem e hortaliças de folhas, em geral, podem sofrer danos causados pela geada, principalmente as geadas tardia ou precoces, acarretando a quebra de produção, e consequentemente, prejuízos para os agricultores, já que essa produção é base da economia de pequenas propriedades que são predominantes no Estado Catarinense.

Deve-se ter em mente que todas as plantas cultivadas nas latitudes de Santa Catarina, que estão entre 26 e $30^{\circ}$ Sul, são susceptiveis ao congelamento. Segundo Pola (1993), as plantas apresentam diferentes graus de resistência às baixas temperaturas, variando entre as variedades de uma mesma espécie, com o estádio de desenvolvimento da cultura, com o estado de nutrição e sanidade das plantas e com o teor de umidade e vigor do vegetal.

Outra característica peculiar ao Estado de Santa Catarina são as bruscas variações de temperaturas dentro de pequenas áreas, devido ao relevo acidentado. Isto faz com que as plantas tenham respostas diferenciadas à geada, dependendo da exposição do terreno.

A seguir são apresentados os efeitos da geada nas principais culturas do Estado de Santa Catarina. 


\subsubsection{Bananeira}

A geada é um dos grandes problemas para os produtores de banana no Estado. Os produtores evitam o plantio em baixadas, optando pelas encostas onde o ar frio não se acumula. As plantas que já frutificaram e que estão prontas para serem colhidas, não apresentam perdas econômicas quando atingidas por geadas, porém, aquelas que estão na fase de floração e com cachos pequenos não comercializáveis, podem ter até $100 \%$ de perda da produção (Santiago Bertoni, 1926)

\subsubsection{Cana-de-açúcar}

A parte inferior da planta normalmente não sofre dano algum por estar protegida pelas folhas superiores; estas ao contrário sofrem danos, porém, sem muitos prejuizos quando a planta está no máximo desenvolvimento, pronta para ser cortada (Santiago Bertoni, 1926)

\subsubsection{Hortaliças}

Todas as plantas são suceptiveis ao congelamento, porém, aquelas mais tenras e suculentas, como no caso das folhosas, apresentam maior susceptibilidade. No Estado, os maiores prejuizos são registrados quando ocorrem geadas precoces ou tardias (Acosta et al., 1973)

\subsubsection{Milho}

É uma cultura de grande expressão no Estado e base econômica da agricultura de pequenas propriedades, tanto para consumo como para alimentação dos rebanhos. Segundo Carter (1995), os maiores danos são causados pela geada tardia, que pode ocorrer após a germinaçã் e do $9^{\circ}$ ao $10^{\circ}$ estágio fenológico com 65 a $100 \%$ de dados. Já Elmore \& Doupnick Junior (1995) verificaram maiores danos na cultura do milho entre a $3^{\mathrm{a}}$ e a $4^{\mathrm{a}}$ folha. Estudo realizado por Duarte et al. 
(1995), com milho safrinha, mostrou que geadas nas fases de frutificação e de maturação reduziram a produtividade de grãos em mais de $50 \%$.

\subsubsection{Pastagens}

As pastagens de inverno são largamente utilizadas no Estado devido à sensibilidade existente nas cultivares perenes que praticamente desaparecem dos campos nos periodos de inverno. Porém, a época de floração de algumas cultivares pode ser atrasada quando ocorrem geadas tardias (Santiago Bertoli, 1926). Espécies de trevo são em sua maioria tolerantes às geadas, porém, se infectadas com alguma doença no período de inverno, a resistência às geadas diminui (Caradus, 1995).

\subsubsection{Trigo}

Como cultivo de inverno, é relativamente resistente à geada. No entanto, na fase de floração a cultura torna-se mais susceptível se cultivada em baixadas, onde $o$ ar frio se acumula (Acosta et al., 1973).

\subsubsection{Erva mate}

Como as plantas de erva são mais susceptíveis ao congelamento, o seu cultivo ocorre em sub-bosques. Esses bosques são, geralmente, naturais ou podem ser limpos para possibilitar um melhor manejo. Caso o bosque não esteja uniforme, na ocorrência de geadas fortes, as plantas que não estão protegidas serão lesadas. Quando ocorrem geadas advectivas, as plantas mais prejudicadas são aquelas que se encontram nos extremos da área do bosque (Santiago Bertoli, 1926).

\subsection{Medidas preventivas para minimização dos efeitos da geada}

A geada por ser um fenômeno atmosférico dependente de uma série de fatores, dificilmente pode ser evitada em grandes áreas, no entanto, algumas 
medidas ou práticas podem ser adotadas pelos agricultores de modo a minimizar o seu efeito sobre as culturas.

Muitas medidas são simples, não envolvendo custos elevados. Outras, porém, exigem o emprego de equipamentos específicos, o que acaba elevando 0 custo do controle. No entanto, o mais importante na adoção de medidas preventivas é se conhecer a real possibilidade de ocorrência de geadas na região e os periodos de maior probabilidade para que não sejam gastos recursos desnecessários (Bootsma, 1980).

A seguir são descritas algumas medidas utilizadas para minimização dos efeitos da geada.

\subsubsection{Local e época de semeadura}

Por meio de modelos probabilisticos adequados, pode-se estimar os niveis de risco de ocorrência de temperaturas mínimas indicativas de geadas em diferentes locais e períodos do ano, com base em séries históricas

Estefanel et al. (1978) verificou que o conhecimento dos riscos de geada pode, além de delimitar áreas favoráveis às culturas, também fixar épocas de plantio e colheita menos sujeitas às geadas.

Vários são os trabalhos que determinaram a probabilidade de ocorrência de geadas para os estados brasileiros, podendo-se destacar os de Camargo et al. (1993) e Camargo \& Alfonsi (1995) para o Estado de São Paulo, Grodzki et al. (1996) para o Estado do Paraná, Acosta et al. $(1971$; 1972) e Massignam \& Dittrich (1998) para o Estado de Santa Catarina, e Acosta et al. (1973) e Estefanel et al. (1978) para o Estado do Rio Grande do Sul.

\subsubsection{Utilização de variedades resistentes}

O conhecimento das temperaturas letais das diferentes espécies cultivadas, tanto anuais como perenes, possibilita a escolha daquelas mais adequadas a cada 
região, em função do nível de tolerância às baixas temperaturas (Sentelhas et al. 1999).

O estudo de variedades resistentes às geadas tem sido realizado para a utilização de espécies mais adaptáveis a regiões onde as condições de temperaturas mínimas limita o cultivo. Caradus (1995) observou que dentre 13 variedades de trevo, 3 chegaram a uma resistência surpreendente até temperaturas abaixo de $10^{\circ} \mathrm{C}$ negativos.

Outro exemplo é apresentado por Sentelhas et al. (1999) comparando duas variedades de abacate: a "geada" que resiste até $-4,0^{\circ} \mathrm{C}$ e a Pollock cuja temperatura letal é de $-1,0^{\circ} \mathrm{C}$. Nesse caso, a variedade geada é mais recomendada para áreas onde o risco de gear é maior ou onde as condições de relevo favorecem a ocorrência de menores temperaturas.

\subsubsection{Medidas topo e microclimáticas}

\subsubsection{Medidas topoclimáticas}

As medidas topoclimáticas se baseiam na localização mais correta dos cultivos dentro de uma bacia hidrográfica (encostas, espigões e terrenos convexos) e deve ser executada com vários anos de antecedência (Camargo, 1997). Nesse caso, deve-se dar preferência para a instalação de culturas perenes nas áreas situadas nas encostas e nos espigões, onde não ocorre acúmulo de ar frio, porém, tomando-se o cuidado de evitar a presença de maciços como matas e culturas de porte alto à jusante, que sirvam de barreira ao escoamento do frio. Outra opção é - plantio próximo a grandes faixas de água, devido ao seu efeito termo-regulador, o que ameniza o resfriamento (Sentelhas et al., 1999).

O local de plantio dentro de uma propriedade pode ser dividido, tomando para culturas susceptiveis às geadas, preferencialmente, áreas bem drenadas, que não possuam baixadas que possibilitem o acúmulo de ar frio, em encostas com mais de $8 \%$ de declive, e no caso de espigões, estes devem ter mais de $4 \%$ de declive (Camargo, 1997). 


\subsubsection{Medidas microclimáticas}

Constituem medidas de curto ou longo prazo. As medidas de curto prazo são: manter o solo das culturas limpo e livre de mato ou qualquer tipo de cobertura que impeça a passagem da radiação solar para o solo e seu aquecimento, e desobstruir encostas para que ar frio possa escoar livremente (Camargo, 1997).

As medidas de longo prazo, são aquelas realizadas no plantio das culturas perenes, consistindo da arborização ou sombreamento das áreas, de modo a alterar o balanço de radiação da cultura de interesse. Essa medida vem sendo empregada principalmente na cultura do cafeeiro, no Estado do Paraná, apresentando resultados promissores (Caramori et al., 1995 ; Caramori, 1997)

\subsubsection{Medidas de proteção direta}

Para Valli (1972), os métodos mais eficientes e econômicos de proteção das culturas contra danos causados por geada são os de aquecimento e de ventilação, os quais consistem em romper a camada de inversão térmica que ocorre em noites de geada. No entanto, essas práticas envolvem alto custo, o que as tornam impraticáveis para os pequenos produtores.

Camargo (1997) sugere a aplicação de neblina artificial para reduzir a perda de calor da superfície, evitando, assim, a inversão térmica. A neblina absorve a radiação de ondas longas emitida pela superfície e as contra-emite, reduzindo 0 resfriamento. Essa prática necessita de planejamento antecipado envolvendo várias propriedades a nivel de microbacia.

Em pequena escala, a geada pode ser evitada com anteparos como cobertura com vidros, com tecidos e com plástico transparente (Ometto, 1981). Heldwein et al. (1995) observaram, em Santa Maria (RS), que o uso de estufas com cobertura plástica de polietileno de baixa densidade (PEBD) ou acetato de vinil etileno (EVA) reduziram a emissão de onda longa evitando que a temperatura atingisse níveis letais às plantas no interior da estufa. 


\section{MATERIAL E MÉTODOS}

\subsection{Dados de temperatura mínima do ar no abrigo meteorológico e na relva}

Foram utilizados dados de temperatura mínima do ar obtidos no abrigo meteorológico (Tma) e na relva (Tmr) de oito localidades do Estado de Santa Catarina (Tabela 3 e Figura 1). Esses dados foram obtidos junto ao Centro de Informações do Estado de Santa Catarina (CIASC), sendo o banco de dados meteorológicos proveniente da Empresa de Pesquisa Agropecuária e Extensão Rural de Santa Catarina S. A.(EPAGRI).

Tabela 3. Relação das localidades utilizadas no presente estudo com as respectivas coordenadas geográficas.

\begin{tabular}{lccc}
\hline Localidade & Altutude $(\mathrm{m})$ & Latitude $(\mathrm{S})$ & Longitude $(\mathrm{W})$ \\
\hline Campos Novos & 946 & $27^{\circ} 24^{\prime} 00^{\prime \prime}$ & $51^{\circ} 12^{\prime} 00^{\prime \prime}$ \\
Chapecó & 679 & $27^{\circ} 07^{\prime} 00^{\prime \prime}$ & $53^{\circ} 37^{\prime} 00^{\prime \prime}$ \\
Lages & 937 & $27^{\circ} 48^{\prime} 44^{\prime \prime}$ & $50^{\circ} 19^{\prime} 37^{\prime \prime}$ \\
Ponte Cerrada & 1100 & $26^{\circ} 52^{\prime} 20^{\prime \prime}$ & $52^{\circ} 01^{\prime} 30^{\prime \prime}$ \\
São Joaquim & 1800 & $28^{\circ} 19^{\prime} 00^{\prime \prime}$ & $49^{\circ} 56^{\prime} 00^{\prime \prime}$ \\
São Miguel D'Oeste & 754 & $26^{\circ} 44^{\prime} 00^{\prime \prime}$ & $53^{\circ} 35^{\prime} 00^{\prime \prime}$ \\
Urussanga & 48 & $28^{\circ} 31^{\prime} 18^{\prime \prime}$ & $49^{\circ} 19^{\prime} 03^{\prime \prime}$ \\
Videira & 775 & $27^{\circ} 00^{\prime} 14^{\prime \prime}$ & $51^{\circ} 09^{\prime} 00^{\prime \prime}$ \\
\hline
\end{tabular}

Fonte: CIASC/EPAGRI. 


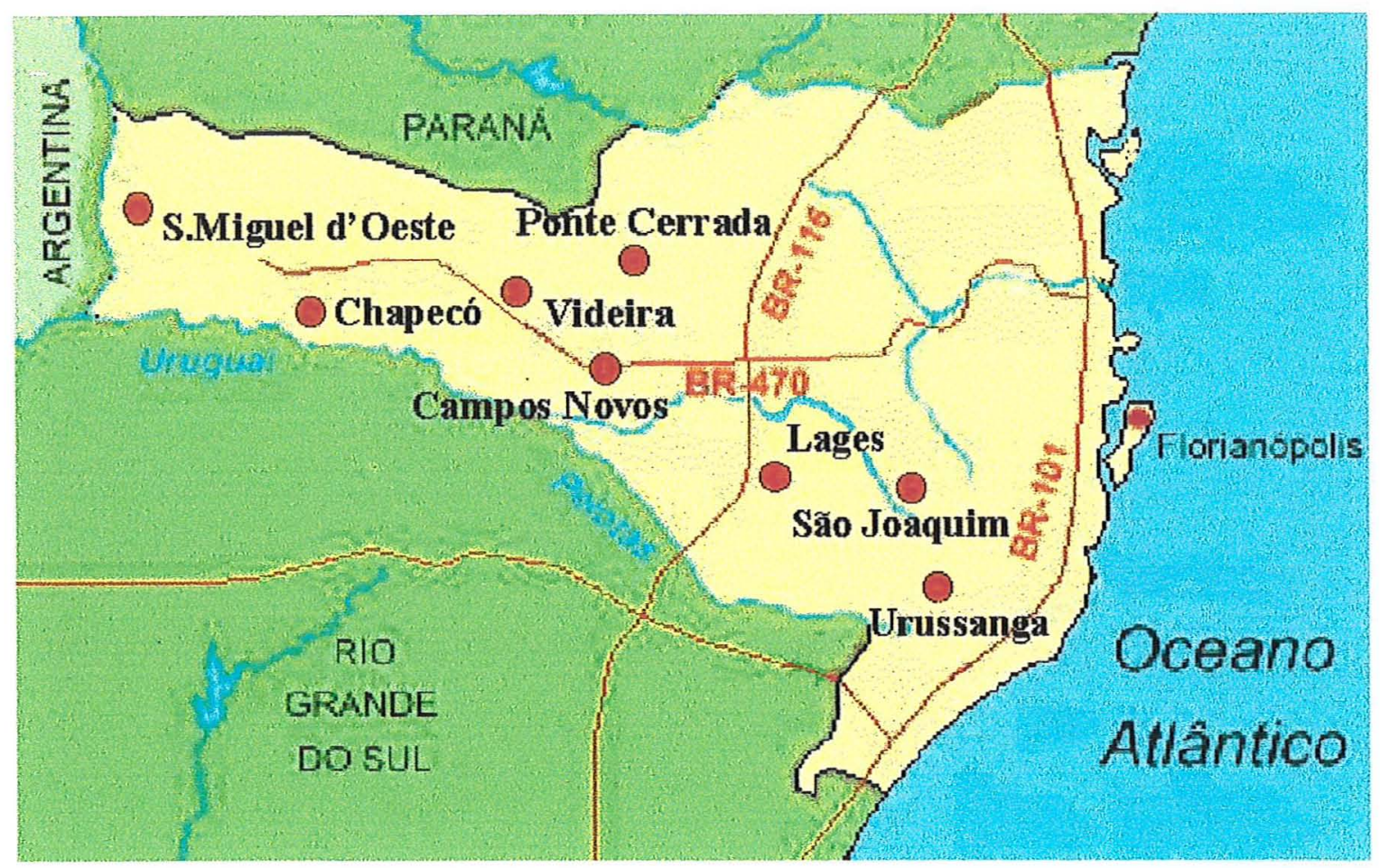

Figura 1 - Localização geográfica dos postos meteorológicos do Estado de Santa Catarina, cujos dados foram utilizados no presente estudo.

\subsection{Determinação da diferença média e da correlação entre a temperatura mínima do ar no abrigo meteorológico e na relva}

Para a obtenção da diferença média e da correlação entre a temperatura mínima no abrigo e na relva utilizaram-se as séries históricas disponíveis, para cada localidade, com essas variáveis (Tabela 4).

A diferença entre a temperatura mínima obtida no abrigo, a 1,5m de altura, e na relva, a 0,05m de altura, característica de noite com inversão térmica (Figura 2), foi determinada sempre que a $\mathrm{Tmr}$ foi menor ou igual a $0,0^{\circ} \mathrm{C}$. Foram obtidos os valores médios dessa diferença $(\Delta T)$, para cada localidade, com os respectivos desvios - padrões, calculando-se também as medianas, as modas e os coeficientes de variação. 
Tabela 4. Relação das localidades e respectivos números de anos utilizados para a obtenção da diferença média e da correlação entre a temperatura mínima do ar no abrigo e na relva.

\begin{tabular}{lcc}
\hline Localidade & Período & Total de anos \\
\hline Campos Novos & $85-96$ & 12 \\
Chapecó & $85-96$ & 11 \\
Lages & $84-96$ & 13 \\
Ponte Cerrada & $86-96$ & 10 \\
São Joaquim & $85-96$ & 12 \\
São Miguel D'Oeste & $88-96$ & 09 \\
Urussanga & $85-96$ & 10 \\
Videira & $84-96$ & 11 \\
\hline
\end{tabular}

Fonte: CIASC/EPAGRI.

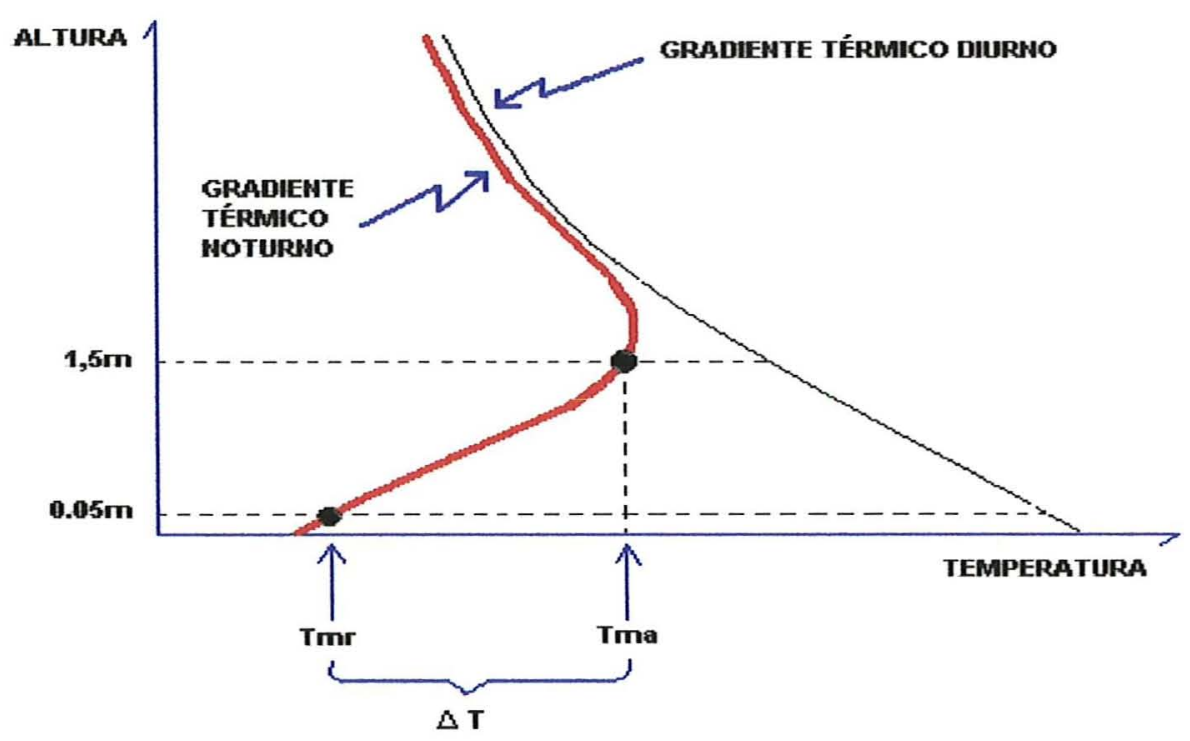

Figura 2 - Esquema indicando os gradientes térmicos diurno e noturno num dia de geada, onde observa-se a inversão térmica, a temperatura mínima do abrigo (Tma), na relva (Tmr) e a diferença entre elas $(\Delta \mathrm{T})$.

Além disso, estabeleceu-se para cada uma das localidades a correlação entre Tma e Tmr, aplicando-se dois tipos de ajuste: linear e polinomial, gerando equações de estimativa da Tmr em função da Tma. 
3.3 Probabilidade de ocorrência de determinada diferença de temperatura mínima entre abrigo e relva

Os dados da diferença de temperatura mínima entre 0 abrigo e a relva foram classificados em 15 intervalos de classe $\left(0,0\right.$ a $1,0^{\circ} \mathrm{C} ; 1,1$ a $2,0^{\circ} \mathrm{C} ; 2,1$ a $3,0^{\circ} \mathrm{C} ; \ldots \ldots \ldots \ldots ; 13,0^{\circ} \mathrm{C} ; 13,1$ a $14,0^{\circ} \mathrm{C} ; 14,1$ a $15,0^{\circ} \mathrm{C}$ ), para cada localidade, de modo a se analisar a distribuição dessa diferença e determinar a probabilidade de sua ocorrência. Para tanto foram utilizadas três funções de distribuição:

a) Distribuição Normal:

$f(x)=\frac{1}{\sigma x \sqrt{2 \pi}} e^{-0.5\left(\frac{x-\mu}{\sigma}\right)^{2}}$

em que; $\mu$ é a média; $\sigma$ é o desvio padrão; e $\mathrm{x}$ o valor da diferença de temperatura a ser considerada.

b) Distribuição Log-normal:

$f(x)=\frac{1}{\sigma x \sqrt{2 \pi}} e^{-0.5\left(\frac{L n-\mu}{\sigma}\right)^{2}}$

c) Distribuição Gama:

$f(x)=\frac{1}{\beta^{\gamma} \Gamma(\gamma)} x^{\gamma-1} e^{-\frac{x}{\beta}}$

em que: $\gamma$ e $\beta$ são estimados pelo método da máxima verossimilhança, como segue: 
$\gamma=\frac{1}{4 A}\left(1+\sqrt{1+4 \frac{A}{3}}\right)$

$$
A=\operatorname{Ln} \bar{x}-\frac{\sum \operatorname{Ln} x_{i} f}{N}
$$

$\beta=\frac{\bar{x}}{\gamma}$

Para verificar qual das funções de distribuição melhor se ajustou aos dados observados utilizou-se o teste de aderência qui-quadrado $\left(\chi^{2}\right)$, dado por:

$$
\chi^{2} \text { calc }=\sum\left[\frac{(\text { Fobs }- \text { Fest })^{2}}{\text { Fest }}\right]
$$

em que: Fobs é a frequência observada de cada intervalo de classe e Fest é a frequência estimada ou teórica. Para a aceitação da hipótese de igualdade entre as duas frequências utilizou-se, conforme Assis et al. (1996), o nivel de 95\% de probabilidade e 12 graus de liberdade, haja visto que ambas as funções de distribuição utilizam 2 parâmetros.

\subsection{Probabilidade mensal de ocorrência de geadas de diferentes intensidades}

Para determinação da probabilidade mensal de ocorrência de geadas, nas localidades analisadas, dividiu-se esse fenômeno em diversos níveis de intensidade ou severidade. Esta divisão foi baseada na classificação proposta por Acosta et al. (1971), com pequenas modificações. A Tabela 5 apresenta a classificação adotada neste trabalho. 
Tabela 5. Níveis de intensidade ou severidade de geadas com respectiva denominação e intervalo de temperatura na relva. Adaptado de Acosta et al.(1971).

\begin{tabular}{clc}
\hline Nível & Classificação & Temperatura da relva \\
\hline 1 & Geada fraca & 0,0 a $-1,9^{\circ} \mathrm{C}$ \\
2 & Geada moderada & $-2,0$ a $-3,9^{\circ} \mathrm{C}$ \\
3 & Geada medianamente forte & $-4,0$ a $-5,9^{\circ} \mathrm{C}$ \\
4 & Geada forte & $-6,0$ a $-7,9^{\circ} \mathrm{C}$ \\
5 & Geada muito forte & $-8,0$ a $-9,9^{\circ} \mathrm{C}$ \\
6 & Geada extremamente forte & $<-9,9^{\circ} \mathrm{C}$ \\
\hline
\end{tabular}

Para a determinação das probabilidades foram utilizados dados de temperatura mínima obtido no abrigo meteorológico de toda a série histórica disponível de cada localidade, sendo que esta difere em algumas localidades da série de dados utilizada para a obtenção da diferença de temperatura entre abrigo e a relva. Na Tabela 6 são apresentadas as localidades com o respectivo número de anos da série de dados utilizados para a determinação da probabilidade de ocorrência de geadas.

Tabela 6. Relação das localidades e respectivos números de anos utilizados para a determinação da probabilidade de ocorrência de geadas.

\begin{tabular}{lcc}
\hline Localidade & Período & Total de anos \\
\hline Campos Novos & $85-96$ & 12 \\
Chapecó & $73-96$ & 23 \\
Lages & $48-96$ & 44 \\
Ponte Cerrada & $86-96$ & 10 \\
São Joaquim & $65-96$ & 31 \\
São Miguel D'Oeste & $88-96$ & 09 \\
Urussanga & $48-96$ & 43 \\
Videira & $70-96$ & 27 \\
\hline
\end{tabular}

Fonte: CIASC/EPAGRI.

Para a classificação dos diferentes níveis de geada foram considerados os dados de Tma $\leq 10^{\circ} \mathrm{C}$ que, posteriormente, foram corrigidos para $\mathrm{Tmr}$ de acordo com as equações lineares e polinomiais obtidas pela correlação $\mathrm{Tmr} \times \mathrm{Tma}$, 
descrita no item 3.2, sendo feito mensalmente de modo a se obter a frequência de ocorrência mensal de geadas com diferentes intensidades.

A probabilidade de ocorrência foi determinada por meio da frequência relativa (FR), dada por:

$$
F R=\frac{n}{N+1}
$$

em que: $\mathbf{n}$ é o número de eventos de geada a um dado nível, num determinado mês e $\mathbf{N}$ é o número total de eventos de geada no ano, no referido nível de intensidade.

\subsection{Probabilidade de ocorrência de geadas de diferentes intensidades em cada mês}

Com o mesmo conjunto de dados utilizados no item 3.4 , processou-se a determinação da probabilidade de ocorrência de diferentes intensidades de geada em cada mês. A classificação dos intervalos foi feita de acordo com a Tabela 5.

Essa determinação visou identificar dentro de cada mês qual o nível de geada mais frequente, ou seja, de maior probabilidade de ocorrência. Assim, como no item 3.4, a probabilidade de ocorrência de geadas de diferentes intensidades em cada mês foi determinada por meio da frequência relativa (FR), que neste caso é dada por:

$$
F R=\frac{n^{\prime}}{N^{\prime}+1}
$$

em que: $n$ ' é o número de eventos de geada a um dado nível de intensidade no mês em questão e $\mathbf{N}^{\prime}$ é o total de eventos de geada nesse mesmo mês. 


\section{RESULTADOS E DISCUSSÃO}

\subsection{Determinação da diferença média e da correlação entre a temperatura mínima do ar no abrigo meteorológico e na relva}

Com os dados da diferença de temperatura mínima do ar no abrigo meteorológico e na relva calculou-se a média, mediana, moda, desvio padrão e coeficiente de variação dessa variável para as 8 localidades estudadas (Tabela 7).

Tabela 7. Medidas de tendência da diferença de temperatura mínima entre o abrigo e a relva para 8 localidades do Estado de Santa Catarina.

\begin{tabular}{lccccc}
\hline Local & Média $\left({ }^{\circ} \mathrm{C}\right)$ & Moda $\left({ }^{\circ} \mathrm{C}\right)$ & Mediana $\left({ }^{\circ} \mathrm{C}\right)$ & D.P $\left({ }^{\circ} \mathrm{C}\right)$ & C.V.\% \\
\hline Campos Novos & 3,4 & 3,0 & 3,0 & 1,6 & 38 \\
Chapecó & 4,2 & 4,4 & 4,1 & 1,5 & 30 \\
Lages & 4,6 & 4,0 & 4,6 & 1,6 & 27 \\
Ponte Cerrada & 3,3 & 1,4 & 3,0 & 1,9 & 41 \\
São Joaquim & 4,8 & 4,0 & 4,2 & 2,8 & 35 \\
São Migual D'Oeste & 2,2 & 1,0 & 2,1 & 0,9 & 44 \\
Urussanga & 2,1 & 1,5 & 1,8 & 1,1 & 51 \\
Videira & 2,2 & 2,2 & 2,2 & 0,8 & 41 \\
\hline
\end{tabular}

De acordo com a Tabela 7 pode-se observar uma diferença média de $3,3^{\circ} \mathrm{C}$ considerando-se todas as localidades analisadas. Quando comparadas as localidades verifica-se que a menor diferença média, igual a $2,1^{\circ} \mathrm{C}$, foi observada em Urussanga e a maior em São Joaquim, com $4,8^{\circ} \mathrm{C}$. Os resultados obtidos encontram-se dentro da faixa de variação estabelecida por outros autores, como Sentelhas et al. (1995) que obtiveram $\Delta T$ variando de 3,3 a $5,7^{\circ} \mathrm{C}$ em 10 localidades paulistas e Grodzki et al. (1996) que encontraram $\Delta T$ variando de 2,8 a $3,8^{\circ} \mathrm{C}$ em diversas localidades do Estada do Paraná. Os valores extremos de $\Delta T$ 
foram obtidos para as duas localidades que possuem a menor $(48 \mathrm{~m})$ e a maior $(1800 \mathrm{~m})$ altitude, respectivamente, o que dá indícios da correlação entre essas duas variáveis

A Figura 3 mostra a relação da média das diferenças entre temperatura mínima do abrigo meteorológico e da relva $(\Delta T)$ com a altitude.

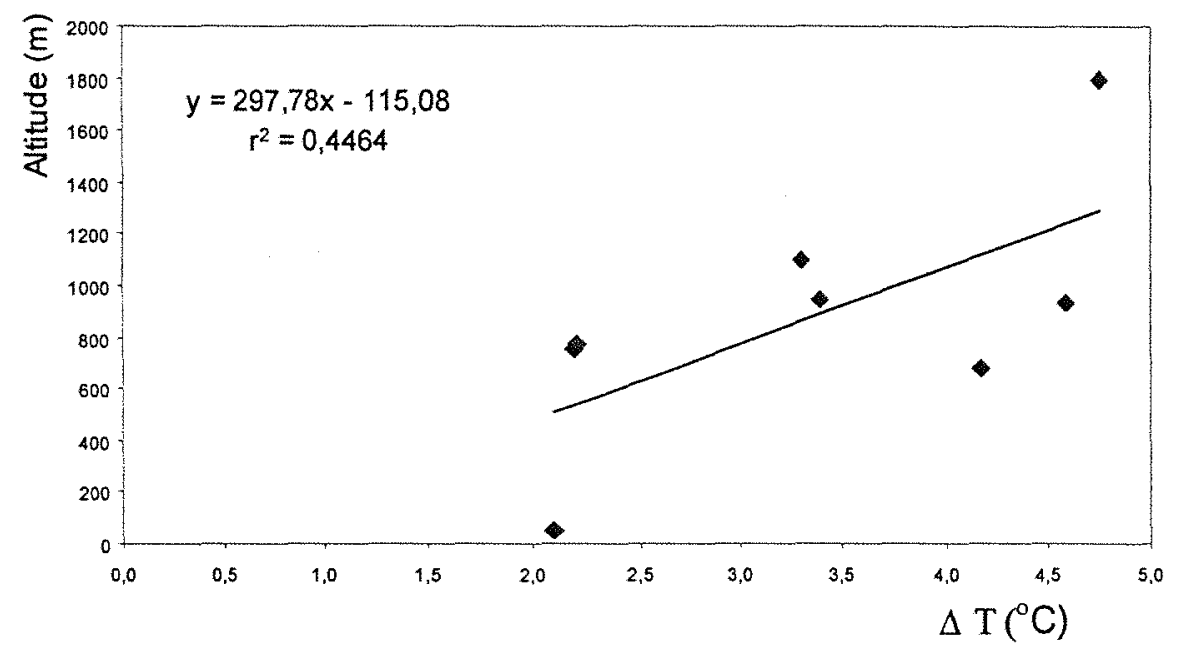

Figura 3 - Relação entre a média da diferança de temperatura mínima do abrigo meteorológico e da relva $(\Delta T)$ com a altitude.

Pode-se observar na Figura 3 que apesar de $r^{2}$ ter sido baixo, explicando apenas $44,64 \%$ das dispersões entre os pontos, encontrou-se uma certa linearidade nessa relação. Os dados estão de acordo com Massignam \& Ditrich (1998), que verificaram para vinte e uma estações meteorológicas no Estado de Santa Catarina, que as variaçōes no número médio mensal e da probabilidade de ocorrência de geada, na sua maioria, estão relacionadas com a altitude.

Além da altitude, outros fatores são decisivos na magnitude das diferenças existentes entre a temperatura mínima no abrigo e na relva, entre eles as condições atmosféricas, representadas pela umidade, nebulosidade e velocidade do vento, elementos relacionados ao balanço de radiação e à formação de inversão térmica em noites de intenso resfriamento, ou seja, sob o domínio de uma massa de ar polar. 
De acordo com Bootsma (1976b), a nebulosidade no período noturno e a velocidade do vento explicaram cerca de $74 \%$ da variação da diferença entre a temperatura mínima do abrigo e da relva, sendo as maiores diferenças obtidas em noites de baixa velocidade do vento e com céu limpo. Sentelhas et al. (1995) verificaram para 10 localidades do Estado de São Paulo, que a diferença de temperatura mínima entre o abrigo e a relva, em noites de geada, pode ser estimada em função de variáveis como a velocidade do vento e a nebulosidade e que a Tmr pode ser estimada a partir da Tma e da temperatura do ponto de orvalho às 21 horas. Na validação das equações de estimativa propostas, os autores encontraram erros variando de 0,8 a $1,4^{\circ} \mathrm{C}$ para a estimativa da $\mathrm{Tmr}$ e de $0,9 \mathrm{e}$ $1,5^{\circ} \mathrm{C}$ para a estimativa da $\Delta \mathrm{T}$.

$\mathrm{Na}$ tentativa de se estimar a Tmr em função da Tma foram estabelecidas as relações entre essas temperaturas para as 8 localidades analisadas. As Figuras $4 \mathrm{e}$ 5 apresentam essas relações e os ajustes linear e polinomial entre Tma e Tmr. Observa-se que houve relação entre as duas variáveis, Tma e Tmr, tanto pelo ajuste linear como pelo polinomial, indo de encontro ao que se verificou nos trabalhos de Bootsma (1976a) e de Sentelhas et al. (1995) que estabeleceram correlações entre a temperatura mínima da relva e elementos meteorológicos. Os coeficientes de determinação mostraram-se relativamente baixos para ambos os ajustes, entre 0,40 e 0,86 para linear e entre 0,53 e 0,88 para polinomial. Esses baixos valores de $r^{2}$, podem ser explicados levando-se em consideração que outras variáveis atmosféricas interferem na inversão térmica. Os valores de temperatura mínima da relva podem variar, diminuindo a diferença entre esta e a temperatura mínima do abrigo por aumento na pressão de vapor d'água, na nebulosidade e na velocidade do vento (Bootsma, 1976a e Sentelhas et al.,1995).

Adotando-se $o$ ajuste polinomial, estabeleceu-se equações de estimativa da Tmr em função da Tma. Essas equações foram utilizadas para resgatar os dados de temperatura mínima da relva a partir da temperatura mínima do abrigo, de modo a expandir a série de dados para determinação da probabilidade de ocorrência de geadas no Estado de Santa Catarina 

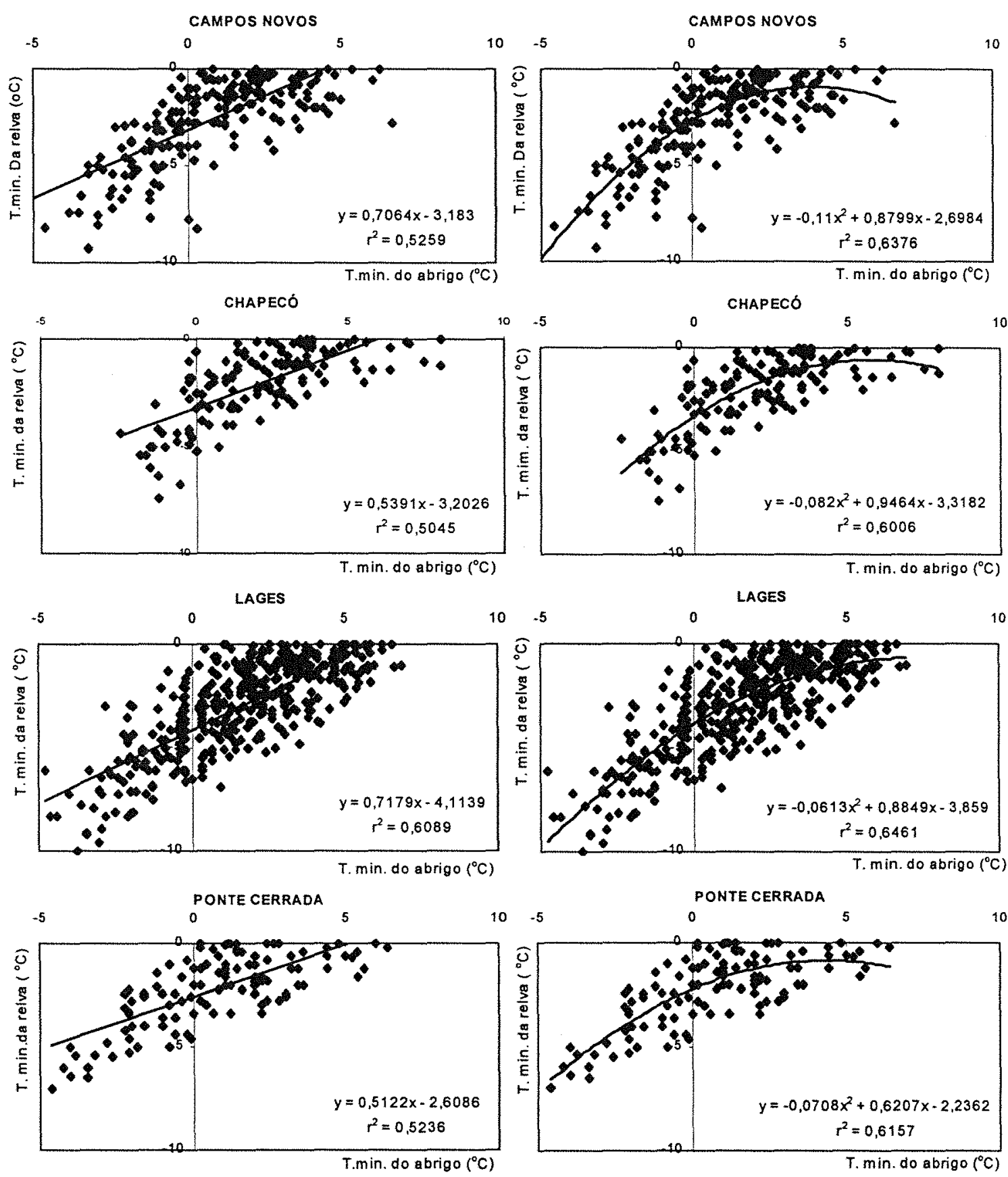

Figura 4 - Relação entre a temperatura mínima do ar obtida na relva e no abrigo para as localidades de Campos Novos, Chapecó, Lages e Ponte Cerrada, no Estado de Santa Catarina. 

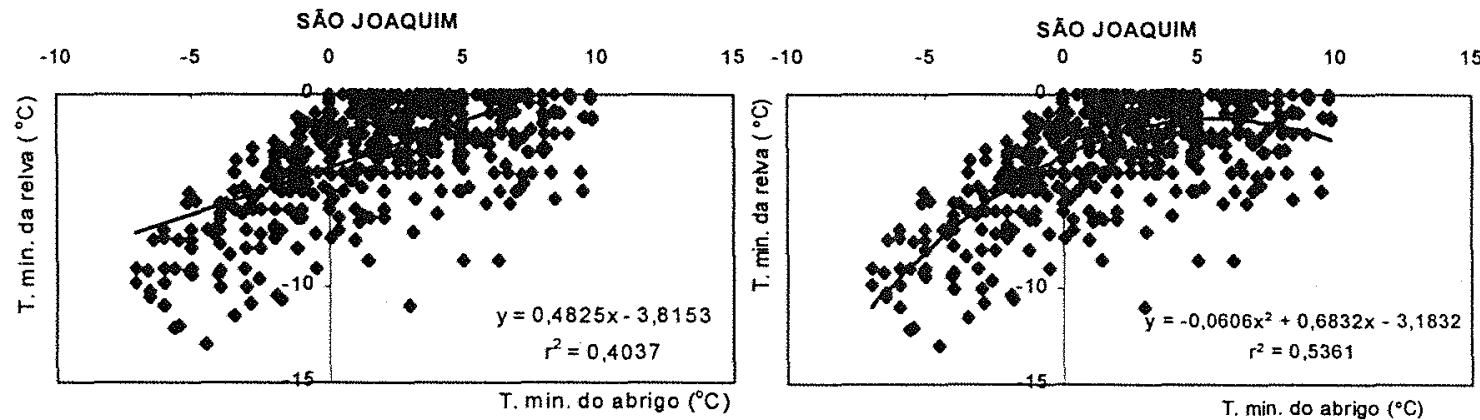

T. min. do abrigo $\left({ }^{\circ} \mathrm{C}\right)$
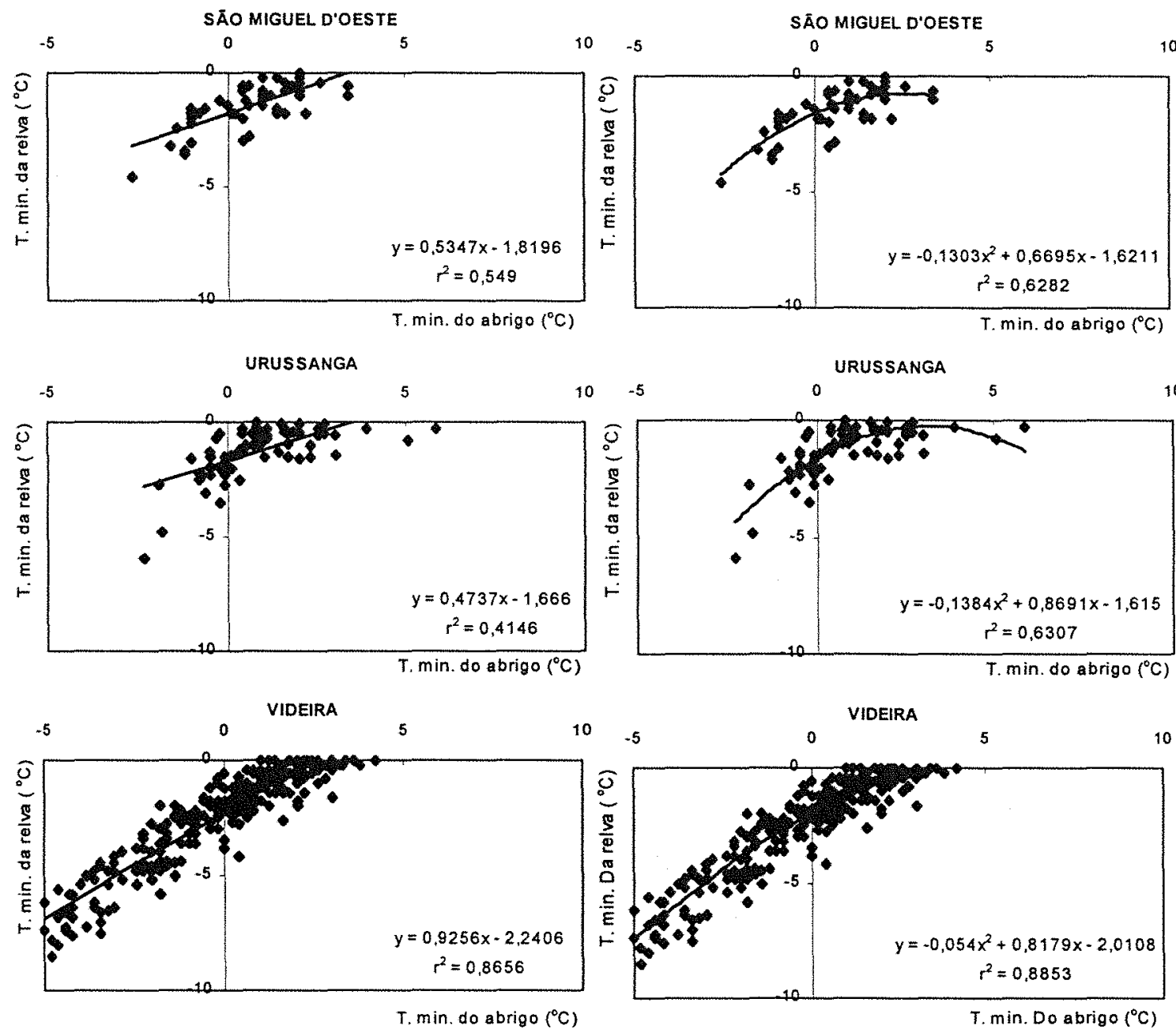

Figura 5 - Relação entre a temperatura mínima do ar obtida na relva e no abrigo para as localidades de São Joaquim, São Miguel D'Oeste, Urussanga e Videira, no Estado de Santa Catarina. 


\subsection{Probabilidade de ocorrência de determinada diferença de temperatura entre o abrigo e a relva}

Os valores de frequência em que as geadas ocorreram, distribuídos em 15 classes conforme item 3.3, foram submetidos a três modelos de distribuição probabilística. As frequências observadas $e$ as estimadas pelos modelos probabilisticos são apresentadas na Figura 6. Para verificar o melhor ajuste entre as funções probabilisticas foi realizado $\circ$ teste $\chi^{2}$, cujos valores são apresentados na Tabela 8

Observa-se na Figura 6 e Tabela 8 que os melhores ajustes foram com a distribuição normal para as localidades de Chapecó, Lages, Ponte Cerrada, São Miguel D'Oeste e Videira, log-normal para Campos Novos e Urussanga e gama para São Joaquim. A partir dessas distribuições, foram estabelecidas as probabilidades de ocorrência de cada intervalo de classe de $\Delta T$, assim como feito por Sentelhas et al. (1995) (Tabela 9).

Observa-se na Tabela 9 que as maiores frequências de ocorrência de $\Delta T$ encontraram-se na faixa de 0,1 a $3,0^{\circ} \mathrm{C}$ nas localidades de Campos Novos, São Miguel D'Oeste, Urussanga e Videira, com $49,4 \%, 66,7 \%, 61,6 \%$ e $75,2 \%$ de probabilidade, respectivamente. $\mathrm{Na}$ localidade de Ponte Cerrada a maior frequência de $\Delta \mathrm{T}$ encontra-se na faixa de 2,1 a $4,0^{\circ} \mathrm{C}$ com $45,1 \%$ da probabilidade. Em Chapecó e São Joaquim, $\Delta T$ entre 3,1 e $5,0^{\circ} \mathrm{C}$ foi a que apresentou a maior frequência, respectivamente, com $45,7 \%$ e $30,0 \%$ de probabilidade de ocorrência. Finalmente, em Lages a maior frequência foi no intervalo de 4,1 a $6,0^{\circ} \mathrm{C}$ com $46,2 \%$ de probabilidade de ocorrer. 

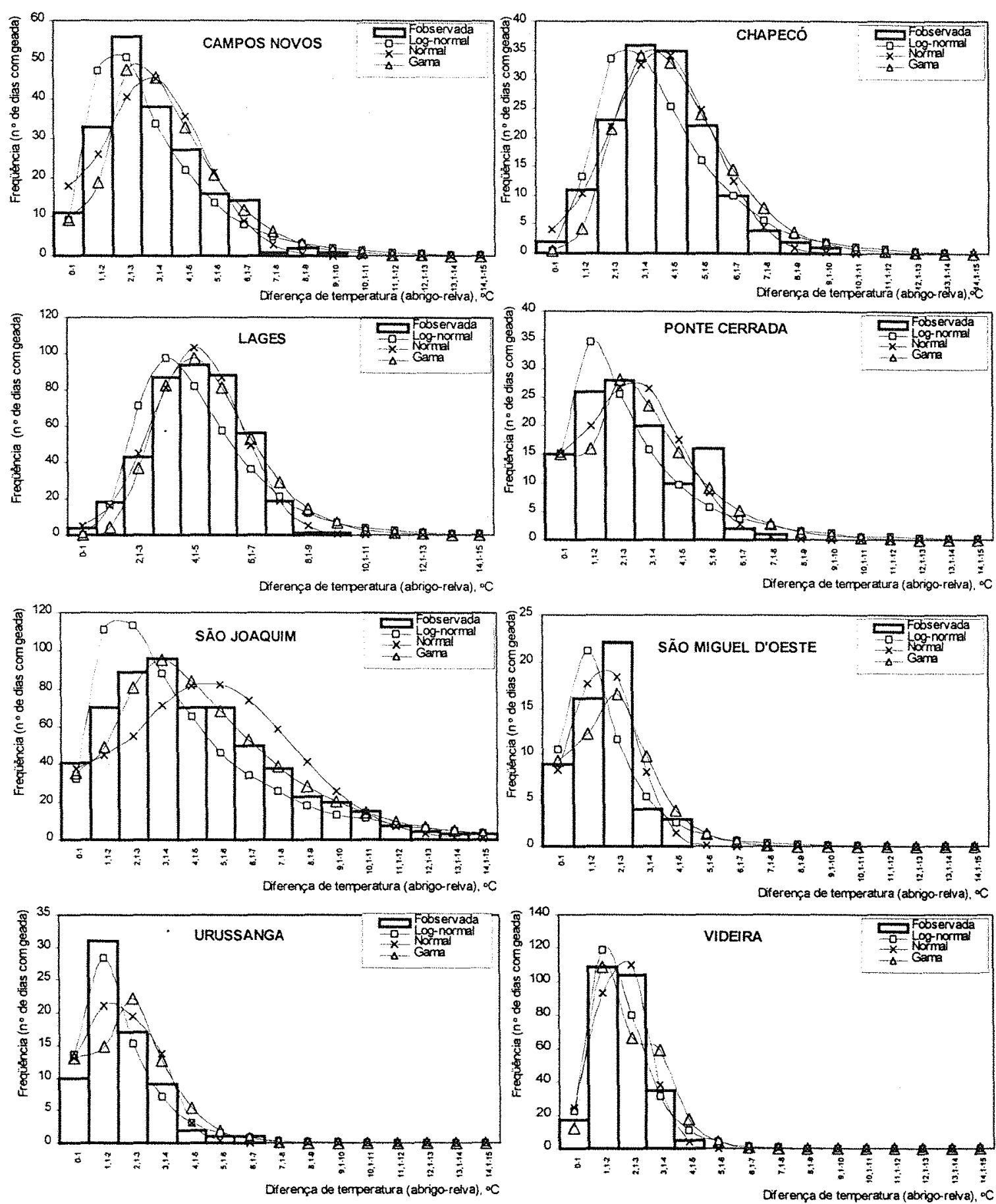

Figura 6 - Frequência observada e estimada pelos modelos probabilisticos: normal, gama e log normal, da diferença de temperatura mínima abrigo-relva em noites de geada, em 8 localidades de Santa Catarina. 
Tabela 8. Valores do teste do qui-quadrado $\left(\chi^{2}\right)$ para três modelos probabilisticos no ajuste da diferença de temperatura mínima do ar entre abrigo e relva, em noites de geada para 8 localidades de Santa Catarina $\left(\chi^{2} 0,05\right.$ Tabela $=21,03$ ).

\begin{tabular}{lccc}
\hline Localidade & Normal & Gama & Log normal \\
\hline Campos Novos & $30,98^{\text {ns }}$ & $22,70^{\text {ns }}$ & $17,88^{*}$ \\
Chapecó & $5,84^{*}$ & $24,81^{\text {ns }}$ & $19,60^{*}$ \\
Lages & $5,68^{*}$ & $193,67^{\text {ns }}$ & $148,48^{\text {ns }}$ \\
Ponte Cerrada & $14,17^{\star}$ & $24,33^{\text {ns }}$ & $28,58^{\text {ns }}$ \\
São Joaquim & $95,66^{\text {ns }}$ & $16,48^{*}$ & $56,87^{\text {ns }}$ \\
São Miguel D'Oeste & $4,65^{*}$ & $8,61^{*}$ & $13,86^{*}$ \\
Urussanga & $38,64^{\text {ns }}$ & $23,58^{\text {ns }}$ & $3,52^{*}$ \\
Videira & $6,22^{*}$ & $46,27^{\text {ns }}$ & $19,27^{*}$ \\
\hline
\end{tabular}

* - Significancia para $\alpha=0,05 ;$ ns - Não significativo.

Tabela 9. Probabilidade de ocorrência da diferença de temperatura mínima do ar entre 0 abrigo e a relva $(\Delta T)$ em noites de geada, de diversas localidades do Estado de Santa Catarina.

\begin{tabular}{ccccccccc}
\hline$\Delta \mathrm{T}$ & \multicolumn{7}{c}{ Probabilidade de ocorrência (\%) } \\
\cline { 2 - 9 }$\left({ }^{\circ} \mathrm{C}\right)$ & C.Novos & Chapecó & Lages & P.Cerrada & S.Joaquim & S.M.Oeste & Urus. & Videira \\
\hline 0,0 a 1,0 & 4,6 & 2,8 & 1,2 & 12,9 & 5,9 & 15,4 & 19,2 & 9,2 \\
0,1 a 2,0 & 23,8 & 7,0 & 4,0 & 16,9 & 8,2 & 32,6 & 39,9 & 34,5 \\
2,1 a 3,0 & 25,6 & 15,0 & 11,0 & 22,6 & 13,6 & 34,1 & 21,7 & 40,7 \\
3,1 a 4,0 & 16,9 & 22,4 & 19,8 & 22,5 & 16,0 & 14,9 & 10,0 & 14,2 \\
4,1 a 5,0 & 11,0 & 23,3 & 25,1 & 14,9 & 14,0 & 2,7 & 4,5 & 1,4 \\
5,1 a 6,0 & 6,8 & 17,0 & 21,1 & 7,1 & 11,4 & 0,2 & 2,2 & 0,0 \\
6,1 a 7,0 & 4,1 & 8,6 & 11,9 & 2,4 & 8,8 & 0,0 & 1,1 & 0,0 \\
7,1 a 8,0 & 2,5 & 3,0 & 4,5 & 0,6 & 6,5 & 0,0 & 0,6 & 0,0 \\
8,1 a 9,0 & 1,6 & 0,7 & 1,2 & 0,1 & 4,7 & 0,0 & 0,3 & 0,0 \\
9,1 a 10,0 & 1,0 & 0,2 & 0,2 & 0,0 & 3,4 & 0,0 & 0,2 & 0,0 \\
10,1 a 11,0 & 0,7 & 0,0 & 0,0 & 0,0 & 2,4 & 0,0 & 0,1 & 0,0 \\
11,1 a 12,0 & 0,4 & 0,0 & 0,0 & 0,0 & 1,6 & 0,0 & 0,1 & 0,0 \\
12,1 a 13,0 & 0,3 & 0,0 & 0,0 & 0,0 & 1,1 & 0,0 & 0,0 & 0,0 \\
13,1 a 14,0 & 0,2 & 0,0 & 0,0 & 0,0 & 0,8 & 0,0 & 0,0 & 0,0 \\
14,1 a 15,0, & 0,1 & 0,0 & 0,0 & 0,0 & 0,5 & 0,0 & 0,0 & 0,0 \\
\hline
\end{tabular}

Considerando-se os eventos extremos, ou seja, $\Delta \mathrm{T}$ maior do que $7^{\circ} \mathrm{C}$, observa-se que a maior probabilidade de ocorrência desse evento é em São Joaquim com $21 \%$, sendo que nessa localidade ainda há cerca de $6,4 \%$ de chance de $\Delta \mathrm{T}$ ser maior do que $10^{\circ} \mathrm{C}$. Para as demais localidades, o evento $\Delta T>7^{\circ} \mathrm{C}$ é 
baixo, sendo da ordem de 6,7\% em Campos Novos, 5,7\% em Lages, 3,9\% em Chapecó, 1,3\% em Urussanga, 0,7\% em Ponte Cerrada e nem chegando a ocorrer nas localidades de São Miguel D'Oeste e Videira. Sentelhas et al. (1995) encontrou resultados semelhantes para o Estado de São Paulo, onde a maior frequência de ocorrência de $\Delta T$ é no intervalo de 2,1 a $4,0^{\circ} \mathrm{C}$, com $49,65 \%$ de probabilidade. Os autores verificaram também que a probabilidade de $\Delta T$ ser maior do que $7,0^{\circ} \mathrm{C}$ é de apenas $5,0 \%$.

\subsection{Probabilidade mensal de ocorrência de geadas de diferentes intensidades}

Com os dados de temperatura mínima da relva resgatados a partir da temperatura do abrigo utilizando equações de regressão polinomial, Figuras 4 e 5 , estimou-se a frequência relativa de ocorrência de geadas para as 8 localidades do Estado de Santa Catarina (Tabelas 10 a 17).

A seguir são apresentadas as frequências relativas mensais de ocorrência de geadas, considerando-se diferentes níveis de temperatura minima na relva e a correspondente temperatura no abrigo meteorológico dada pela diferença de temperatura entre 0 abrigo e a relva $(\Delta T)$, obtida para cada uma das oito localidades.

Tabela 10. Frequência relativa mensal de ocorrência de geadas de diferentes intensidades na localidade de Campos Novos (SC).

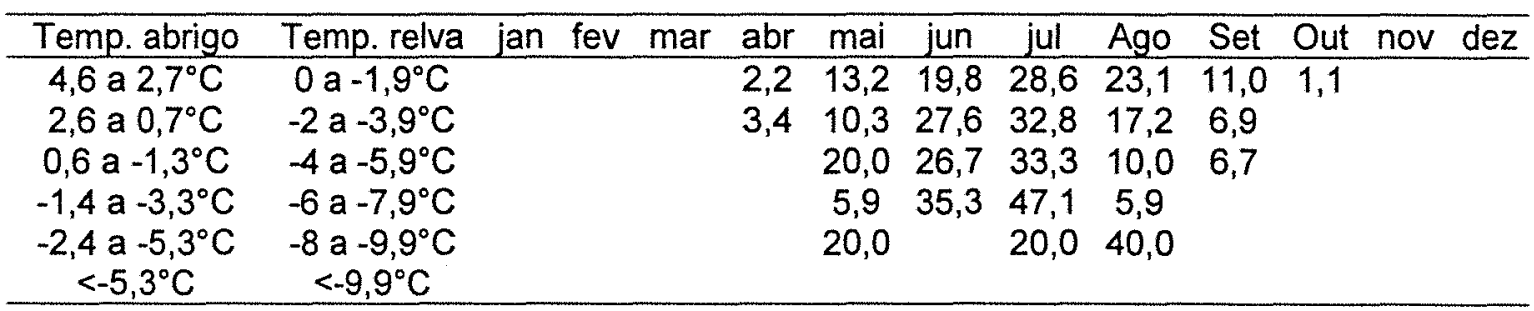

Observa-se para a localidade de Campos Novos (Tabela 10) uma maior concentração de eventos de geada entre os meses de maio e setembro para o três primeiros niveis de severidade. Para todos os niveis, o mês de maior frequência foi 
julho, com exceção do $5^{\circ}$ nível em que o maior valor foi em agosto. Isso difere dos resultados obtidos por Steckert \& Altholf (1983), que verificaram uma maior frequência de geadas para Campos Novos em junho. Não há probabilidade de ocorrência de geadas extremamente fortes em Campos Novos.

Tabela 11. Frequência relativa mensal de ocorrência de geadas de diferentes intensidades na localidade de Chapecó (SC).

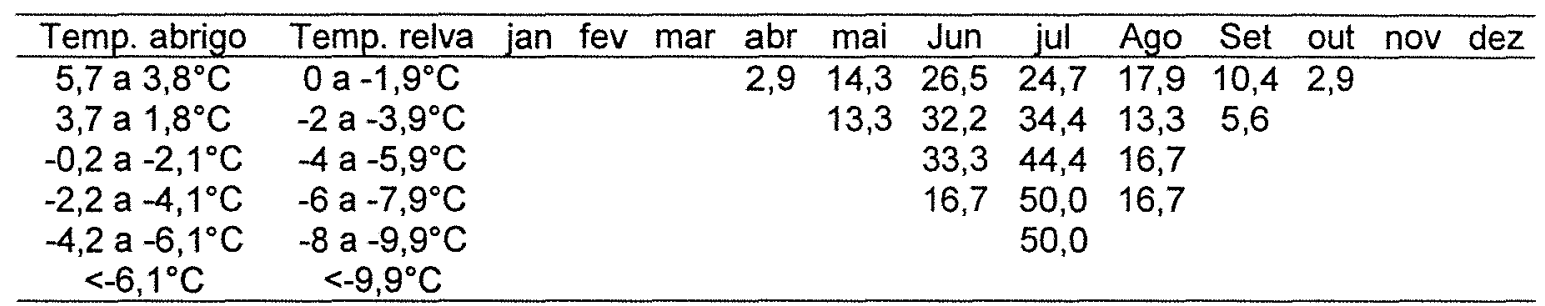

No caso de Chapecó (Tabela 11), ocorreu maior concentração dos eventos de geada, em todos os niveis de severidade, entre os meses de maio e agosto, ocorrendo geadas fracas e moderadas dos meses de maio e setembro. Com exceção das geadas fracas, que ocorreram com maior frequência em junho, todos os outros niveis tiveram maior ocorrência em julho, o que também foi observado por Steckert \& Althoff (1993). Em Chapecó não existe probabilidade de ocorrer geadas extremamente fortes.

Tabela 12. Frequência relativa mensal de ocorrência de geadas de diferentes intensidades na localidade de Lages (SC).

\begin{tabular}{|c|c|c|c|c|c|c|c|c|c|c|c|c|}
\hline Temp. abrigo & Temp. relva Jan & fev & mar & $a b r$ & mai & jun & jul & Ago & set & out & nov & $\mathrm{dez}$ \\
\hline 6,1 a $4,2^{\circ} \mathrm{C}$ & $0 \mathrm{a}-1,9^{\circ} \mathrm{C}$ & 0,1 & 0,8 & 8,6 & 17,5 & 18,1 & 21,4 & 15,4 & 8,9 & 6,0 & 2,5 & 0,6 \\
\hline 4,1 a $2,2^{\circ} \mathrm{C}$ & -2 a $-3,9^{\circ} \mathrm{C}$ & & 0,2 & 3,2 & 19,2 & 23,5 & 23,7 & 17,0 & 9,7 & 2,8 & 0,6 & \\
\hline 2,1 a $0,2^{\circ} \mathrm{C}$ & -4 a $-5,9^{\circ} \mathrm{C}$ & & & 1,4 & 15,4 & 27,7 & 27,0 & 19,6 & 7,7 & 0,7 & & \\
\hline $0,1 \mathrm{a}-1,8^{\circ} \mathrm{C}$ & -6 a $-7,9^{\circ} \mathrm{C}$ & & & & 11,6 & 39,5 & 29,1 & 14,0 & 4,7 & & & \\
\hline$-1,9$ a $-3,8^{\circ} \mathrm{C}$ & $-8 \mathrm{a}-9,9^{\circ} \mathrm{C}$ & & & & 7,1 & 21,4 & 35,7 & 28,6 & & & & \\
\hline$<-3,9^{\circ} \mathrm{C}$ & $<-9,9^{\circ} \mathrm{C}$ & & & & & 66,7 & & & & & & \\
\hline
\end{tabular}

$\mathrm{Na}$ localidade de Lages (Tabela 12), há ampla distribuição de eventos de geada com probabilidade de ocorrência em quase todos os meses do ano, o que pode ser, em parte, devido à altitude (Massignam \& Dittrich, 1998). Apesar das maiores probabilidades para todos os níveis se encontrarem entre os meses de 
maio a agosto, existem, ainda, probabilidade de $9,5 \%$ de ocorrerem geadas fracas de fevereiro a abril, e 18,0\% de setembro a dezembro. Para as geadas moderadas a probabilidade chega, ainda, a $3,4 \%$ para fevereiro e abril e $13,1 \%$ de setembro a novembro.

Tabela 13. Frequência relativa mensal de ocorrência de geadas de diferentes intensidades na localidade de Ponte Cerrada (SC).

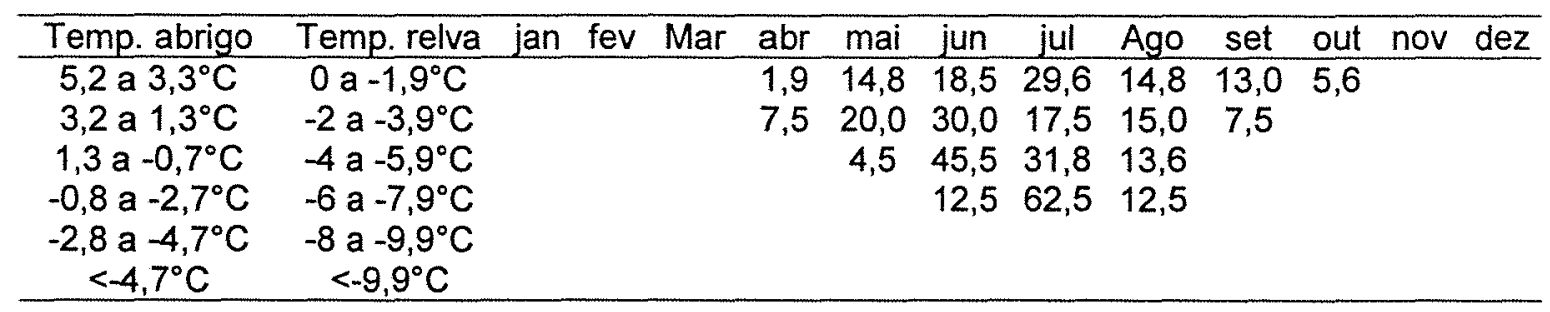

Ponte Cerrada (Tabela 13) não apresenta probabilidade de ocorrerem eventos de geadas fortes e muito fortes. As maiores probabilidades estão entre junho e agosto, sendo que para geadas fracas e fortes a maior probabilidade é em julho e geadas moderadas e medianamente fortes é em junho. Observando-se também os meses de agosto e maio verifícam-se probabilidades de $4,5 \%$ a $20,0 \%$ para os três primeiros niveis.

Tabela 14. Frequência relativa mensal de ocorrência de geadas de diferentes intensidades na localidade de São Joaquim (SC).

\begin{tabular}{cccccccccccccc}
\hline Temp. abrigo & Temp. relva jan & fev & Mar & abr & mai & Jun & jul & Ago & set & out & nov & dez \\
\hline 7,0 a $5,1^{\circ} \mathrm{C}$ & $0 \mathrm{a}-1,9^{\circ} \mathrm{C}$ & 1,8 & 1,1 & 2,7 & 8,9 & 12,9 & 12,2 & 12,6 & 12,2 & 11,6 & 10,9 & 8,1 & 4,8 \\
5,0 a $3,1^{\circ} \mathrm{C}$ & $-2 \mathrm{a}-3,9^{\circ} \mathrm{C}$ & 0,4 & & 0,8 & 5,4 & 12,3 & 19,0 & 17,6 & 19,9 & 13,2 & 7,5 & 3,1 & 0,8 \\
3,0 a $1,1^{\circ} \mathrm{C}$ & $-4 \mathrm{a}-5,9^{\circ} \mathrm{C}$ & 1,2 & & & 2,2 & 13,2 & 24,3 & 27,2 & 17,1 & 10,1 & 2,6 & 0,5 & 1,4 \\
1,0 a $-0,9^{\circ} \mathrm{C}$ & $-6 \mathrm{a}-7,9^{\circ} \mathrm{C}$ & & & & 1,1 & 13,8 & 5,3 & 39,4 & 25,5 & 12,8 & & & 1,1 \\
$-1 \mathrm{a}-2,9^{\circ} \mathrm{C}$ & $-8 \mathrm{a}-9,9^{\circ} \mathrm{C}$ & & & & & 3,3 & 60,0 & 25,0 & 5,0 & 1,7 & & & 3,3 \\
$<-2,9^{\circ} \mathrm{C}$ & $<-9,9^{\circ} \mathrm{C}$ & & & & & 9,1 & 18,2 & 27,3 & 36,4 & & & & \\
\hline
\end{tabular}

São Joaquim (Tabela 14) é a localidade de maior altitude dentre as estudadas $(1800 \mathrm{~m})$. Essa localidade apresenta probabilidade de geada em todos os niveis de severidade e para alguns deles em todos os meses do ano, com destaque para os meses de janeiro e dezembro nos quais as geadas fracas tem probabilidade de ocorrência de $1,8 \%$ e 4,8\%, respectivemente. As demais probabilidades concentraram-se entre os meses de maio e agosto. São Joaquim 
pela sua mais marcante característica, a altitude, torna-se limitante para o cultivo das principais culturas de ciclo curto e também das culturas perenes de baixa tolerância ao frio. De acordo com Massignam \& Dittrich (1998), quanto maior a altitude, no Estado de Santa Catarina, maior o número de eventos de geadas e, consequentemente, maior a probabilidade de sua ocorrência.

Tabela 15. Frequência relativa mensal de ocorrência de geadas de diferentes intensidades na localidade de São Miguel D'Oeste (SC).

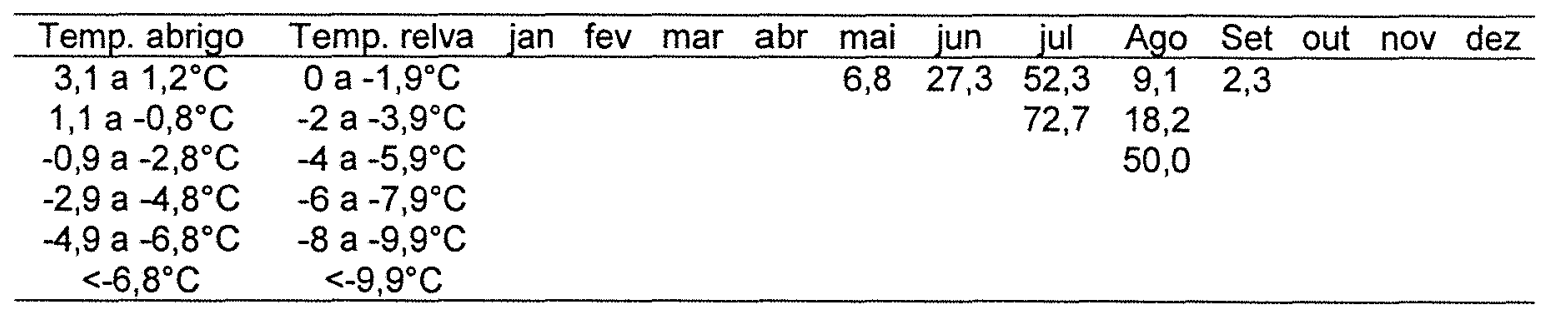

A localidade de São Miguel D'Oeste (Tabela 15) não apresenta probabilidade de ocorrência de geada nos três últimos níveis de severidade. As maiores probabilidades estão concentradas entre os meses de junho e agosto, com probabilidades também entre maio e setembro, estando os demais meses do ano livres da ocorrência de geadas de qualquer nivel de intensidade. Isso se deve a sua baixa latitude $\left(26^{\circ} 44^{\prime} S\right)$, a menor das localidades estudadas, indicando que a frequência de ocorrência de geadas num dado local depende da combinação de diversos fatores, apesar da altitude no Estado de Santa Catarina ser o fator mais importante (Massignam \& Ditrich, 1998).

Tabela 16. Frequência relativa mensal de ocorrência de geadas de diferentes intensidades na localidade de Urussanga (SC).

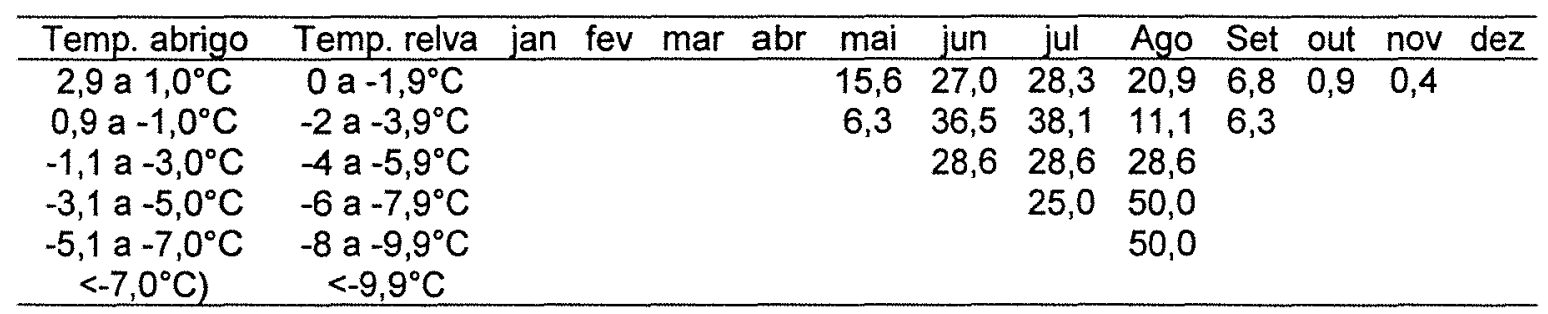

Ao contrário do que foi observado em São Miguel D'Oeste, Urussanga (Tabela 16), a $48 \mathrm{~m}$ de altitude, tem probabilidades de ocorrência de geadas 
comparáveis com localidades de maior altitude, como Chapecó e Ponte Cerrada, observando-se um deslocamento para o final do inverno das maiores probabilidades de gear. Isso se deve a sua maior latitude ( $\left.28^{\circ} 31^{\prime} \mathrm{S}\right)$, a maior entre as localidades analisadas. $O$ mês de agosto tem as maiores probabilidades de ocorrência de geadas com exceção somente para as geadas moderadas que são mais prováveis nos meses de junho e julho. Esses dados são importantes para ressaltar a possibilidade de gear em dada região de potencial agrícola em períodos anteriores e/ou posteriores ao inverno. De acordo com Acosta et al. (1971), quanto maior a probabilidade de gear num dado local, maior a probabilidade de geadas precoces ou tardias.

Tabela 17. Frequência relativa mensal de ocorrência de geadas de diferentes intensidades na localidade de Videira (SC).

\begin{tabular}{cccccccccccc}
\hline Temp. abrigo & Temp. relva jan fev mar & abr & Mai & jun & jul & Ago & set & out nov dez \\
\hline 3,0 a $1,1^{\circ} \mathrm{C}$ & $0 \mathrm{a}-1,9^{\circ} \mathrm{C}$ & 0,3 & 6,0 & 15,2 & 16,7 & 26,4 & 18,4 & 11,2 & 3,7 & 1,7 \\
$1,0 \mathrm{a}-0,9^{\circ} \mathrm{C}$ & $-2 \mathrm{a}-3,9^{\circ} \mathrm{C}$ & & & 2,9 & 15,6 & 28,3 & 26,3 & 17,6 & 7,3 & 1,5 & \\
$-1,0 \mathrm{a}-2,9^{\circ} \mathrm{C}$ & $-4 \mathrm{a}-5,9^{\circ} \mathrm{C}$ & & & 1,3 & 14,1 & 25,6 & 26,9 & 16,7 & 14,1 & & \\
$-3,0 \mathrm{a}-4,9^{\circ} \mathrm{C}$ & $-6 \mathrm{a}-7,9^{\circ} \mathrm{C}$ & & & & 8,3 & 44,4 & 27,8 & 16,7 & & & \\
$-5,0 \mathrm{a}-6,9^{\circ} \mathrm{C}$ & $-8 \mathrm{a}-9,9^{\circ} \mathrm{C}$ & & & & & 40,0 & 40,0 & 13,3 & & & \\
$<-6,9^{\circ} \mathrm{C}$ & $<-9,9^{\circ} \mathrm{C}$ & & & & 50,0 & 25,0 & 12,5 & & & \\
\hline
\end{tabular}

Videira (Tabela 17) também apresenta probabilidade de geadas em todos os niveis de severidade. As maiores probabilidades estão entre junho e agosto, porém, as geadas fracas podem ocorrer de março a novembro, com 0,3 e 1,7\% de probabilidade nesses meses. Já nos meses de abril a setembro, podem ocorrer também geadas moderadas e medianamente fortes, que seriam devastadoras para as culturas nessa época. Nas geadas consideradas extremamente fortes, o mês de junho é o que apresenta maiores probabilidades de ocorrência $(50 \%)$, sendo que para os meses de julho e agosto essa probabilidade cai, respectivamente, para 25,0 e $12,5 \%$. 


\subsection{Probabilidade de ocorrência de geadas de diferentes intensidades em cada mês}

Utilizando-se a mesma série de dados do item 4.3, determinou-se a frequência relativa da ocorrência de geadas de diferentes intensidades dentro de cada mês. Nas Tabelas 18 a 25 são apresentadas essas frequências relativas para as 8 localidades de Santa Catarina estudadas, considerando-se para cada intensidade de geada os valores de temperatura no abrigo e na relva correspondentes. O fato de maior importância com relação a esses dados é de se detectar, para cada localidade e para cada mês, qual a intensidade de geada mais frequênte, informação que servirá de subsídio à tomada de decisões por parte do agricultor, e também no levantamento dos danos causados às culturas agrícolas.

Tabela 18. Frequência relativa da ocorrência de geadas em diferentes intensidades em cada mês para a localidade de Campos Novos (SC).

\begin{tabular}{|c|c|c|c|c|c|c|c|c|c|c|c|}
\hline Temp. abrigo & Temp. relva & jan fev & mar & $a b r$ & mai & jun & jul & Ago & set & out & Nov dez \\
\hline 4,6 a $2,7^{\circ} \mathrm{C}$ & $0 \mathrm{a}-1,9^{\circ} \mathrm{C}$ & & & 40,0 & 44,4 & 36,7 & 40,0 & 55,3 & 58,8 & 50,0 & \\
\hline 2,6 a $0,7^{\circ} \mathrm{C}$ & $-2 \mathrm{a}-3,9^{\circ} \mathrm{C}$ & & & 40,0 & 22,2 & 32,7 & 29,2 & 26,3 & 23,5 & & \\
\hline $0,6 \mathrm{a}-1,3^{\circ} \mathrm{C}$ & -4 a $-5,9^{\circ} \mathrm{C}$ & & & & 22,2 & 16,3 & 15,4 & 7,9 & 11,8 & & \\
\hline$-1,4 \mathrm{a}-3,3^{\circ} \mathrm{C}$ & $-6 \mathrm{a}-7,9^{\circ} \mathrm{C}$ & & & & 3,7 & 12,2 & 12,3 & 2,6 & & & \\
\hline $\begin{array}{c}-2,4 \mathrm{a}-5,3^{\circ} \mathrm{C} \\
<-5,3^{\circ} \mathrm{C}\end{array}$ & $\begin{array}{c}-8 \mathrm{a}-9,9^{\circ} \mathrm{C} \\
<-9,9^{\circ} \mathrm{C}\end{array}$ & & & & 3,7 & & 1,5 & 5,3 & & & \\
\hline
\end{tabular}

Em Campos Novos (Tabela 18) observa-se que os meses de abril, maio, setembro e outubro, que representam os meses de outono e primavera, apresentam probabilidade de ocorrência de geadas, sendo que o mês de maio tem $3,7 \%$ de probabilidade de ocorrência de geadas fortes e muito fortes. De modo geral, as maiores probabilidades de ocorrência são de geadas fracas e moderadas, chegando a totalizar de 50,0 a $80,0 \%$ de probabilidade. 
Tabela 19. Frequência relativa da ocorrência de geadas em diferentes intensidades em cada mês para a localidade de Chapecó (SC).

\begin{tabular}{|c|c|c|c|c|c|c|c|c|c|c|c|}
\hline Temp. abrigo & Temp. relva & jan fev & mar & $a b r$ & Mai & jun & jul & Ago & set & out & Nov dez \\
\hline 5,7 a $3,8^{\circ} \mathrm{C}$ & $0 \mathrm{a}-1,9^{\circ} \mathrm{C}$ & & & 88,9 & 75,5 & 66,7 & 61,1 & 74,6 & 82,9 & 88,9 & \\
\hline 3,7 a $1,8^{\circ} \mathrm{C}$ & -2 a $-3,9^{\circ} \mathrm{C}$ & & & & 22,6 & 26,1 & 27,4 & 17,9 & 14,3 & & \\
\hline$-0,2 \mathrm{a}-2,1^{\circ} \mathrm{C}$ & $-4 a-5,9^{\circ} \mathrm{C}$ & & & & & 5,4 & 7,1 & 4,5 & & & \\
\hline$-2,2$ a $-4,1^{\circ} \mathrm{C}$ & -6 a $-7,9^{\circ} \mathrm{C}$ & & & & & 0,9 & 2,7 & 1,5 & & & \\
\hline$-4,2$ a $-6,1^{\circ} \mathrm{C}$ & $-8 \mathrm{a}-9,9^{\circ} \mathrm{C}$ & & & & & & 0,9 & & & & \\
\hline$<-6,1^{\circ} \mathrm{C}$ & $<-9,9^{\circ} \mathrm{C}$ & & & & & & & & & & \\
\hline
\end{tabular}

A localidade de Chapecó (Tabela 19) apresenta possibilidade de ocorrência de geadas precoces de abril a maio e tardias nos meses de setembro e outubro, sendo mais graves os meses de maio e setembro, quando a probabilidade de geadas moderadas chega a 22,6 e $14,3 \%$, respectivamente.

Tabela 20. Frequência relativa da ocorrência de geadas em diferentes intensidades em cada mês para a localidade de Lages (SC).

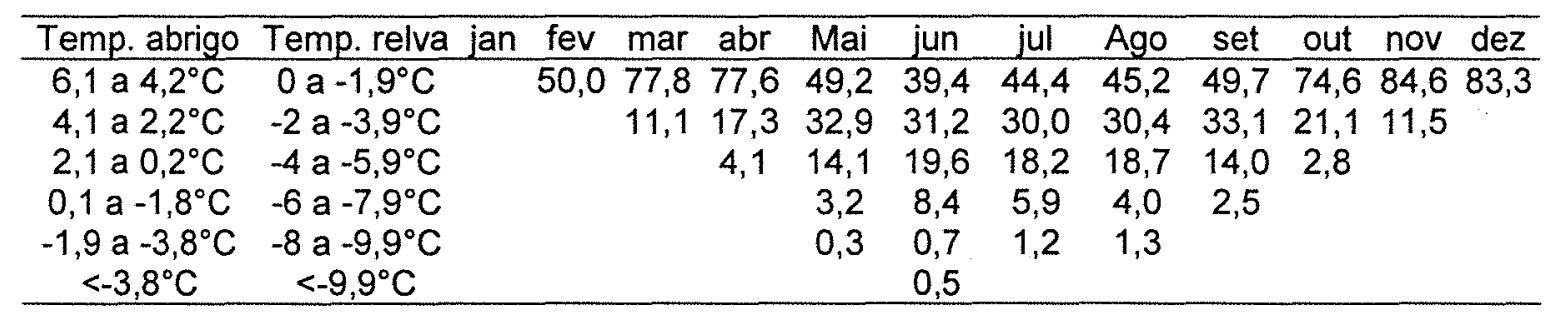

$\mathrm{Na}$ localidade de Lages (Tabela 20), observa-se que nos períodos de fevereiro a maio e de setembro a dezembro, podem ocorrer geadas, o que reflete cuidados nas culturas já instaladas ou no planejamento do plantio. Para todos os meses, as maiores probabilidades são de geadas fracas, porém, existem grandes probabilidades de geadas moderadas e medianamente fortes, especialmente nos meses de abril, maio, setembro e outubro. 
Tabela 21. Frequência relativa da ocorrência de geadas em diferentes intensidades em cada mês para a localidade de Ponte Cerrada (SC).

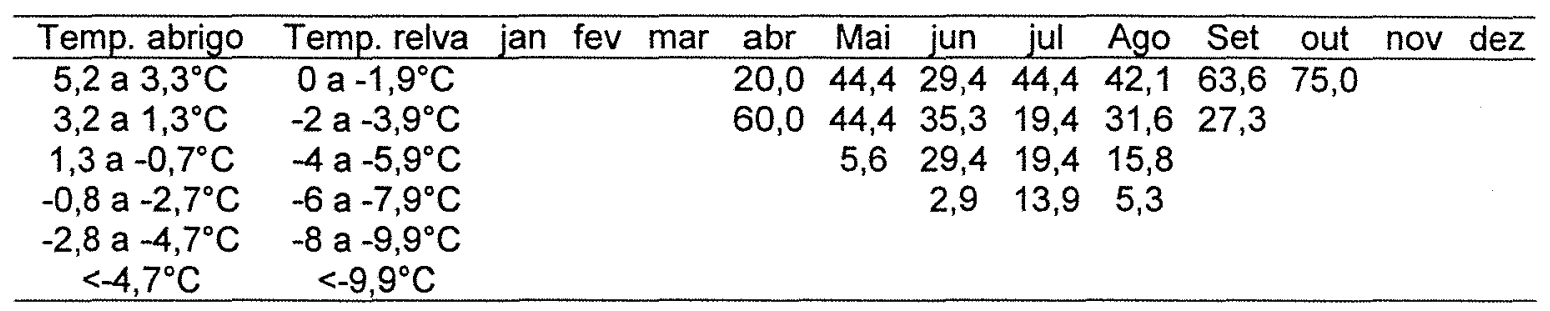

Em Ponte Cerrada (Tabela 21), com exceção de abril e junho, os demais meses apresentam maior probabilidade de ocorrência de geadas fracas Em abril e junho a maior probabilidade é de ocorrerem geadas moderadas e nos meses de abril, maio e setembro, cerca de $82 \%$ das probabilidades são de ocorrer geadas fracas e moderadas, sendo que maio tem ainda $5,6 \%$ de probabilidade de ocorrerem geadas medianamente forte.

Tabela 22. Frequência relativa da ocorrência de geadas em diferentes intensidades em cada mês para a localidade de São Joaquim (SC).

\begin{tabular}{cccccccccccccc}
\hline Temp. abrigo & Temp. relva & jan & fev & mar & abr & mai & jun & jul & Ago & set & Out & nov & dez \\
\hline 7,0 a $5,1^{\circ} \mathrm{C}$ & $0 \mathrm{a}-1,9^{\circ} \mathrm{C}$ & 83,6 & 96,8 & 88,1 & 77,6 & 63,0 & 48,6 & 48,7 & 50,9 & 61,3 & 75,8 & 85,6 & 87,5 \\
5,0 a $3,1^{\circ} \mathrm{C}$ & $-2 \mathrm{a}-3,9^{\circ} \mathrm{C}$ & 6,6 & & 10,7 & 18,9 & 24,2 & 30,5 & 27,6 & 33,5 & 28,1 & 21,2 & 13,3 & 5,9 \\
3,0 a $1,1^{\circ} \mathrm{C}$ & $-4 \mathrm{a}-5,9^{\circ} \mathrm{C}$ & 8,2 & & & 2,8 & 9,7 & 14,5 & 15,8 & 10,7 & 8,0 & 2,8 & 0,8 & 3,9 \\
1,0 a $-0,9^{\circ} \mathrm{C}$ & $-6 \mathrm{a}-7,9^{\circ} \mathrm{C}$ & & & & 0,3 & 2,3 & 0,7 & 5,2 & 3,6 & 2,3 & & & 0,7 \\
$-1 \mathrm{a}-2,9^{\circ} \mathrm{C}$ & $-8 \mathrm{a}-9,9^{\circ} \mathrm{C}$ & & & & & 0,4 & 5,2 & 2,1 & 0,5 & 0,2 & & & 1,3 \\
$<-2,9^{\circ} \mathrm{C}$ & $<-9,9^{\circ} \mathrm{C}$ & & & & 0,2 & 0,3 & 0,4 & 0,6 & & & & \\
\hline
\end{tabular}

Em todos os meses do ano, em São Joaquim (Tabela 22), a maior probabilidade é de ocorrerem geadas fracas, sempre acima de $48,6 \%$. Nos meses de janeiro e dezembro existe 8,2 e $3,9 \%$ de probabilidade de ocorrerem geadas medianamente fortes, existindo ainda, probabilidade de ocorrência de niveis maiores em dezembro, porém, com baixa frequência: $0,7 \%$ para as geadas fortes e $1,3 \%$ para as geadas muito fortes. 
Tabela 23. Frequência relativa da ocorrência de geadas em diferentes intensidades em cada mês para a localidade de São Miguel D'Oeste (SC).

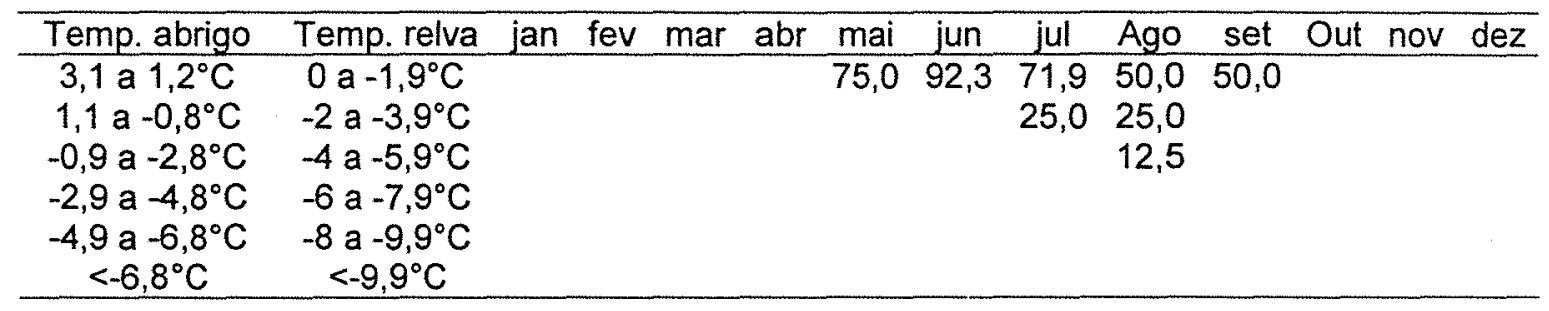

Para São Miguel D'Oeste (Tabela 23), as maiores probabilidades são de ocorrerem geadas fracas para todos os meses. As geadas moderadas podem ocorrer com $25 \%$ de probabilidade, nos meses de inverno, de julho a agosto, e as geadas moderadamente fortes podem ocorrer nos meses de agosto, com 12,5\% de probabilidade. Nessa localidade há risco de geadas precoces e tardias apenas nos meses de maio e setembro, porém de intensidade fraca, não representando grande limitação aos cultivos agrícolas.

Tabela 24. Frequência relativa da ocorrência de geadas em diferentes intensidades em cada mês para a localidade de Urussanga (SC).

\begin{tabular}{ccrrccccc}
\hline Temp. abrigo & Temp. relva jan fev mar abr mai & jun & jul & Ago & set & out nov dez \\
\hline 2,9 a $1,0^{\circ} \mathrm{C}$ & $0 \mathrm{a}-1,9^{\circ} \mathrm{C}$ & 94,6 & 85,3 & 84,9 & 90,0 & 88,4 & 83,3 & 66,7 \\
$0,9 \mathrm{a}-1,0^{\circ} \mathrm{C}$ & $-2 \mathrm{a}-3,9^{\circ} \mathrm{C}$ & 4,3 & 13,0 & 12,9 & 5,4 & 9,3 & & \\
$-1,1 \mathrm{a}-3,0^{\circ} \mathrm{C}$ & $-4 \mathrm{a}-5,9^{\circ} \mathrm{C}$ & & 1,1 & 1,1 & 1,5 & & & \\
$-3,1 \mathrm{a}-5,0^{\circ} \mathrm{C}$ & $-6 \mathrm{a}-7,9^{\circ} \mathrm{C}$ & & & 0,5 & 1,5 & & & \\
$-5,1 \mathrm{a}-7,0^{\circ} \mathrm{C}$ & $-8 \mathrm{a}-9,9^{\circ} \mathrm{C}$ & & & & 0,8 & & \\
$<-7,0^{\circ} \mathrm{C}$ & $<-9,9^{\circ} \mathrm{C}$ & & & & & & \\
\hline
\end{tabular}

A localidade de Urussanga (Tabela 24) também apresenta para todos os meses, de maio até novembro, maior probabilidade de ocorrência de geadas fracas, acima de $83 \%$ de maio a outubro, e de $66,7 \%$ em novembro. As geadas moderadas tem probabilidades baixas, entre 4,3 e $13,0 \%$, sendo que para geadas medianamente forte e forte, essa probabilidade mensal cai para menos de $2 \%$. A concentração da maioria das geadas na classe "fraca" em Urussanga está intimamente ligada a sua baixa altitude, de apenas $48 \mathrm{~m}$, o que, no entanto, não elimina o risco de danos às culturas, especialmente para as mais sensiveis ao frio, como as hortaliças. 
Tabela 25. Frequência relativa da ocorrência de geadas em diferentes intensidades em cada mês para a localidade Videira (SC).

\begin{tabular}{ccccccccccc}
\hline Temp. abrigo & Temp. relva jan fev mar & abr & mai & jun & jul & Ago & set & out & nov dez \\
\hline 3,0 a $1,1^{\circ} \mathrm{C}$ & $0 \mathrm{a}-1,9^{\circ} \mathrm{C}$ & 50,0 & 72,4 & 53,0 & 35,6 & 49,5 & 52,0 & 59,1 & 76,5 & 85,7 \\
$1,0 \mathrm{a}-0,9^{\circ} \mathrm{C}$ & $-2 \mathrm{a}-3,9^{\circ} \mathrm{C}$ & & 20,7 & 32,0 & 35,6 & 29,0 & 29,3 & 22,7 & 17,6 & \\
$-1,0 \mathrm{a}-2,9^{\circ} \mathrm{C}$ & $-4 \mathrm{a}-5,9^{\circ} \mathrm{C}$ & & 3,4 & 11,0 & 12,3 & 11,3 & 10,6 & 16,7 & & \\
$-3,0 \mathrm{a}-4,9^{\circ} \mathrm{C}$ & $-6 \mathrm{a}-7,9^{\circ} \mathrm{C}$ & & & 3,0 & 9,8 & 5,4 & 4,9 & & & \\
$-5,0 \mathrm{a}-6,9^{\circ} \mathrm{C}$ & $-8 \mathrm{a}-9,9^{\circ} \mathrm{C}$ & & & & 3,7 & 3,2 & 1,6 & & & \\
$<-6,9^{\circ} \mathrm{C}$ & $<-9,9^{\circ} \mathrm{C}$ & & & & 2,5 & & & & & \\
\hline
\end{tabular}

Com exceção de janeiro, fevereiro e dezembro, quando não foram observadas geadas em Videira (Tabela 25), todos os meses possuem probabilidade de ocorrerem geadas, especialmente as fracas, as quais tem probabilidade de ocorrência variando de 35,6 a $85,7 \%$. As geadas moderadas, ocorrem com maior probabilidade em relação às geadas medianamente fortes, sendo que fora do período invernal, a maior probabilidade de ocorrer geada é de $32,0 \%$, sendo esta geada moderada, no mês de maio. Vale ressaltar que as geadas precoces podem ocorrer entre abril e maio com intensidade de moderada a medianamente forte em abril (24\%) e de moderada a forte em maio (46\%). Já as geadas tardias tem probabilidade de mais de $39 \%$ de ocorrerem nos níveis moderada e medianamente forte em setembro e $17,6 \%$ de ocorrerem no nível moderado em outubro. 


\section{CONCLUSÕES}

Os resultados obtidos no presente estudo posssibilitam se chegar às seguintes conclusōes:

- A diferença média entre a temperatura mínima do abrigo e da relva $(\Delta T)$, em noites de geada, variou entre as localidades de 2,1 a $4,8^{\circ} \mathrm{C}$, havendo certa tendência da influência da altitude na ordem de magnitude dessa variável.

- Houve correlação entre a temperatura mínima do abrigo e da relva, com a função polinomial apresentando os melhores ajustes, com $r^{2}$ variando de 0,53 a 0,88 , sendo adotadas como equaçōes de estimativa da temperatura mínima da relva.

- Para determinação da probabilidade de ocorrência de dada diferença de temperatura mínima entre $\circ$ abrigo e a relva $(\Delta T)$, utilizou-se a função normal para as localidades de Chapecó, Lages, Ponte Cerrada, São Miguel D'Oeste e Videira, a função log-normal para Campos Novos e Urussanga e a função gama para São Joaquim.

- As maiores probabilidades de $\Delta \mathrm{T}$ encontram-se na faixa de 0,1 a $3,0^{\circ} \mathrm{C}$ para Campos Novos, São Miguel D'Oeste, Urussanga e Videira, com 49,4, 66,7, 69,6 e $75,2 \%$, respectivamente. Em Ponte Cerrada a maior probabilidade $(45,1 \%)$ é de valores de $\Delta \mathrm{T}$ entre 2,1 e 4,0 $0^{\circ} \mathrm{C}$. Em Chapecó e São Joaquim, $\Delta \mathrm{T}$ teve maior probabilidade entre 3,1 e $5,0^{\circ} \mathrm{C}$, respectivamente com 45,7 e $30 \%$. Finalmente, em Lages a maior frequência de valores de $\Delta \mathrm{T}$ foi entre 4,1 e $6,0^{\circ} \mathrm{C}$, com $46,2 \%$ de probabilidade de ocorrer. 
- A probabilidade de gear nas localidades estudadas variou, sendo que as geadas de qualquer intensidade ocorreram de maio a setembro em São Miguel D'Oeste, de maio a novembro em Urussanga, de abril a outubro em Campos Novos, Chapecó e Ponte Cerrada, de março a novembro em Videira e de janeiro/fevereiro a dezembro em São Joaquim e Lages.

- As maiores probabilidades de ocorrência de geadas precoces ou tardias são para as localidades de maior altitude: Lages e São Joaquim, com possibilidade de geadas muito fortes nos meses de maio e setembro. A menor possibilidades de ocorrência de geadas precoces ou tardias é para a localidade de São Miguel D'Oeste onde a probabilidade de gear nos meses de maio a setembro não passa de $7 \%$, sendo essas de intensidade fraca.

- Verificou-se que em todas as localidades analisadas a intensidade de geada mais frequente é a fraca, $\mathrm{Tmr}$ entre 0,0 e $-1,9^{\circ} \mathrm{C}$, com probabilidade de ocorrência variando de 36 a $92 \%$. A geada de intensidade moderada foi a segunda mais frequente com probabilidade variando de 4 a $60 \%$.

- Somente nas localidades de Lages, Videira e São Joaquim há possibilidade de ocorrência de geadas extremamente fortes, com $0,5 \%$ de probabilidade no mês de junho em Lages, com 0,2 a $0,6 \%$ de probabilidade nos meses de maio a agosto em São Joaquim e com $2,5 \%$ de probabilidade no mês de junho em Videira. 


\section{REFERÊNCIAS BIBLIOGRÁFICAS}

ACOSTA, M.J.C.; BEIRSDORF, I.C.; MOTA, F.S. da. Geadas de primavera em Santa Catarina. Contribuição para um calendário agrícola regional. Pesquisa Agropecuária Brasileira, Brasília, v.6, p.67-80, 1971.

ACOSTA, M.J.C.; BEIRSDORF, I.C.; MOTA, F.S. da. Primeiras geadas de outono em Santa Catarina. Ciência e Cultura, v. 24, p.1033 -1045, 1972.

ACOSTA, M.J.C. BEIRSDORF, I.C; MOTA, F.S. da. Primeiras geadas de outono no Rio Grande do Sul. Ciência e Cultura, v.25, n.10, p.971-979,1973.

ARRUDA, H.V.; PINTO, H.S.; PENTEADO, R.S. Modelos probabilisticos para a interpretação da ocorrência de temperaturas mínimas na região de Campinas, SP. In: CONGRESSO BASILEIRO DE AGROMETEOROLOGIA, 2, Pelotas, Anais; Pelotas: UFP, 1981. p. 143-145.

ASSIS, F.N.de.; ARRUDA, H.V.; PEREIRA, A.R. Aplicações de Estatística à Climatologia - Teoria e Prática. Pelotas: Editora Universitária/UFPel, 1996. $161 \mathrm{p}$.

BOOTSMA, A. Estimating grass minimum temperatures from screen minimum values and others climatological parameters. Agricultural Meteorology, Amsterdam, v.16, p.103 - 113, 1976a.

BOOTSMA, A. Estimating minimum temperature and climatological freeze risk in hilly terrain. Agricultural Meteorology, Amsterdam, v.16, p.425 - 443, 1976b. 
BOOTSMA, A. Frost risk survey of Prince Edward Island: P.E.I. Department of Agriculture and Forestry, Ottawa, Canadá, 1980, 35p.

BURIOL G.A. Intensidade das temperaturas minimas e datas de ocorrência de níveis térmicos prejudiciais aos cultivos. Ciência Rural, Santa Maria, v.6, n.1, p. $27-42,1976$.

CAMARGO, A.P. Apontamentos de Agrometeorologia. Apostila da FAZMCG, Esp. Sto. Do Pinhal, 1972.

CAMARGO, A.P. Geada, "o remédio é previnir". 2. ed. Campinas: Coordenadoria de Assistência Técnica Integral - CATI, 1997. 10p. (Boletim Técnico, 227).

CAMARGO, M.B.P.; PEDRO JUNIOR, M.J.; ALFONSI, R.R.; ORTOLANI, A.A. Probabilidade de ocorrência de temperaturas mínimas absolutas mensais e anuais no estado de São Paulo. Bragantia, Campinas, v.52, n.2, p.161-168, 1993.

CAMARGO, M.B.P.; ALFONSI, R.R. Frequência de geadas no Esdado de São Paulo. In: SEMINÁRIO SOBRE A CULTURA DO MILHO SAFRINHA. 3., Assis, Resumos. Assis: IAC, 1995. p.39-43.

CARADUS, J. R. Frost tolerance of Trifolium species. New Zealand Journal of Agricultural Research, v.38, p.157-162, 1995.

CARAMORI, P.H.; ANDRICIOLI FILHO, A.; FARIA R.T. et al. Arborização do cafezal para proteção contra geadas no Estado do Paraná. In: CONGRESSO BRASILEIRO DE AGROMETEOROLOGIA, 9., Campina Grande, Anais. Campina Grande: UFPB, 1995, p.191-192. 
CARAMORI, P.H. Arborização dos cafezais para proteção contra geadas na região Sul do Brasil. In: REUNIÓN ARGENTINA Y LATINOAMERICANA DE AGROMETEOROLOGIA, 7/1., Buenos Aires, 1997. Anais. Buenos Aires: FAA, 1997, p. 18-17.

CARTER, P. R. Late spring frost and posfrost clipping effect on corn growth and yield. Journal of Production Agriculture, v.8, n.2, p.203-207, 1995.

DUARTE, A.P.; KANTHACK, R.A.D.; SPINOSA, W.; ALLIPRANDI, L.F. Efeito da geada na produção e qualidade de grãos de milho. In: SEMINÁRIO SOBRE $A$ CULTURA DO MILHO SAFRINHA. 3., Assis. Resumos. Assis: IAC, 1995. p.6164.

ELMORE, R. W.; DOUPNIK JUNIOR. B. Corn recovery from early-season frost. Journal of Production Agriculture, v.8, n.2, p.199-202, 1995.

ESTEFANEL, V.; BURIOL, G.A.; SACCOL, A.V.; ROMANI, L.B. Variabilidade e probabilidade de ocorrência de temperaturas mínimas absolutas do ar no Estado do Rio Grande do sul. Ciência Rural, Santa Maria, v.8, n.4, p.366-384, 1978.

ESTEFANEL, V.; MANFRON, P.A.; SACCOL, A.V.; et al. Análise das temperaturas mínimas ocorridas em Santa Maria, RS. II- Probabilidade das datas de ocorrência das temperaturas mínimas do ar compreendidas no intervalo de -1 a $9^{\circ} \mathrm{C}$. Ciência Rural, Santa Maria, v.18, n.1, p.15-28, 1988.

ESTEFANEL, V.; SCHNEIDER, F.M.; BURIOL, G.A.; et al. Riscos de ocorrência de temperaturas mínimas do ar prejudiciais aos cultivos agrícolas na região de Santa Maria, RS. Ciência Rural, Santa Maria, v.21, n.3, p.315-335, 1991. 
GRODZKI, L.; CARAMORI, P.A.; BOOSTMA, A.; OLIVEIRA, D de.; GOMES, J. Riscos de ocorrência de geada no estado do Paraná. Revista Brasileira de Agrometeorologia, Santa Maria, v.4, n.1, p.213-220, 1996.

HEBER, U.; SANTARIURS, K.A. Cell death by cold and heat and resistance to extreme temperatures mechanisms of hardening and dehardening. In: PRECHT, H. et al. Temperature and live. Berlin: Springer-Verlag, 1973, cap.C, p.232-292.

HELDWEIN, A.B.; ESTEFANEL, V.; MAFRON, P.A.; et al. Análise das temperaturas mínimas do ar registradas em Santa Maria, RS. I - Estimativas das temperaturas mínimas do ar a $5 \mathrm{~cm}$ do solo relvado e solo desnudo. Ciência Rural, Santa Maria, v.18, n.3, p.3-14, 1988.

HELDWEIN, A.B.; STRECK, N.A.; BURIOL, G.A.; et al. Efeito da cobertura de estufa plástica sobre a temperatura mínima do ar. In: CONGRESSO BRASILEIRO DE AGROMETEOROLOGIA, 9., Campina Grande, Anais. Campina Grande: UFPB, 1995, p.304-306.

HOFFMANN, A.; NACHTIGAL, J.C.; ROSSAL, P.A.L.; ASSIS, F.N. Estimativa da primeira data de outono e última data de primavera com temperaturas do ar menor ou igual a $0^{\circ} \mathrm{C}$ em Pelotas, RS. Revista Brasileira de Agrometeorologia, Santa Maria, v.2, p.65-68, 1994.

MARENGO, J.; CORNEJO, A.; AMURTY, P.S.; NOBRE, C. Cold surges in tropical and estratropical South America. The strong event in june 1994. Monthly Weather Review, v.125, n.22, p.363-390, 1997. 
MASSIGNAM, A. M.; DITTRICH, R. S. Estimativa do número médio e da probabilidade mensal de ocorrência de geadas para o estado de Santa Catarina. Revista Brasileira de Agrometeorologia, Santa Maria, v.6, n.2, p.213-220, 1998.

NERY, J.T.; BALDO, M.C.; MARTINS, M.L.O.F. Variabilidade da temperatura mínima no estado do Paraná. Revista Brasileira de Agrometeorologia, Santa Maria, v.6, n.2, p.207-212, 1998.

OMETTO, J.C. Bioclimatologia vegetal. São Paulo: Editora Agronômica Ceres, 1981. cap. 15, p.341-357: Geada.

PETRI, L.J. Dormência da macieira. In: EMPRESA CATARINENSE DE PESQUISA AGROPECUÁRIA. Manual da cultura da macieira. Florianópolis: EMPASC, 1986. 562p.

POLA, A.C. Probabilidade de ocorrência de geadas em Caçador, SC. Agropecuária Catarinense, v.6, p.46-49, 1993.

ROSENBERG, N.J.; BLAD, B.L.; VERMA, S.B. Microclimate - The Biological Enviroment. New York: John Wiley \& Sons, Inc, 1983. 495p.

SANTIAGO BERTONI, M. El Mentor Agrícola: Guia del Agricultor \& Colono. Puerto Bertoni: Ex Silvis, 1926. p.327-331: Limite de resistência de las plantas a los frios.

SENTELHAS, P.C.; ORTOLANI, A.A. e PEZZOPANE, J.R.M. Diferença de temperatura entre o abrigo meteorológico e a relva, em noites de geada, no Estado de São Paulo. Bragantia, Campinas, v 54, n.2, p. 437-445, 1995. 
SENTELHAS, P.C.; PIZA JUNIOR, C.T.; SIGRISTI, J.M.M. et al. Temperatura letal de diferentes plantas frutiferas tropicais. Bragantia, Campinas, v. 55, n.2, p.231-235, 1996.

SENTELHAS, P.C.; PEREIRA, A.R.; ANGELOCCI, L.R. Meteorologia Agrícola. DCE/ESALQ/USP, 1999. 2.ed. Cap.8, p.97-107: Geada: ocorrência e medidas preventivas.

STECKERT, V.; ALTHOFF, D.A. Distribuição de geadas por decêndio em Campos Novos e Chapecá, Santa Catarina. Florianópolis: EMPASC, 1983. 30p. (Boletim Técnico, 22).

VALLI, V.J. Princípios Básicos Relativos à Ocorrência de Geadas e sua Prevenção. Rio de Janeiro: Ministério da Agricultura / Departamento Nacional de Meteorologia, 1972. 22p. 